\title{
Large and mesoscale variability of the water masses and the deep chlorophyll maximum in the Azores Front
}

\author{
Fiz F. Pérez, M. Gilcoto, and Aida F. Ríos \\ Instituto de Investigacións Mariñas, Consejo Superior de Investigaciones Científicas, Vigo, Spain \\ Received 7 April 2000; revised 20 November 2002; accepted 22 April 2003; published 8 July 2003.
}

[1] Coupling between the physical and biological fields in the upper ocean around the Azores Front (AF) was studied in summer 1998 during an oceanographic cruise to the southern Azores Islands $\left(30^{\circ} \mathrm{N}-38^{\circ} \mathrm{N}\right.$ and $\left.20^{\circ} \mathrm{W}-33^{\circ} \mathrm{W}\right)$. On the basis of conductivitytemperature-depth (CTD), acoustic Doppler current profiler (ADCP), and fluorescence data, several large-scale, mesoscale, and submesoscale physical features are described. The ADCP data and geostrophic field revealed an eastward transport associated with the Azores Current (AC) and weak countercurrents to the south and north of the AC. The water mass field shows a strong latitudinal variation in the AF with an eastward modification. From the surface to $300 \mathrm{dbar}$, the saline distribution strongly defined the AF as a very sharp vertical front. The horizontal thermohaline gradient increased to the east and reached a maximum at approximately 150 dbar. The $16.2^{\circ} \mathrm{C}$ isotherm and 36.2 isohaline at 150 dbar precisely located the AF along the whole area in agreement with the dynamic field. To the west of $26^{\circ} \mathrm{W}$, the Azores Current was $140 \mathrm{~km}$ wide while the $\mathrm{AF}$ was only $15-25 \mathrm{~km}$ wide. To the east of $26^{\circ} \mathrm{W}$ the AC underwent a strong meandering. The water mass characteristics in the southern part of the AF show an eastward evolution between $18^{\circ} \mathrm{C}$ seawater and Madeira Mode Water. Data from a CTDfluorometer mounted on an Undulator system allowed the small-scale structure of AF to be mapped, describing several eddies and meanders. The deep chlorophyll maximum (DCM) showed highest values $\left(0.9\right.$ to $\left.1.2 \mathrm{mg} \mathrm{Chl} \mathrm{m}^{-3}\right)$ toward the west $\left(32^{\circ} \mathrm{W}\right)$ on the southern side of the AF. Chlorophyll concentrations at the DCM $\left(0.4-0.6 \mathrm{mg} \mathrm{Chl} \mathrm{m}^{-3}\right)$ on the northern side of the study area were moderate and fairly constant whereas low values $\left(<0.3 \mathrm{mg} \mathrm{Chl} \mathrm{m}^{-3}\right)$ were measured at the very deep DCM $(120-140 \mathrm{~m})$ in the southeast, associated with high saline waters. Examination of a cold eddy showed similar chlorophyll concentrations to those found on the northern side of the AF. The thermohaline structure of the eddy was similar to the AF, with northern water enclosed within saline and warm southern water. INDEX TERMS: 4283 Oceanography: General: Water masses; 4536 Oceanography: Physical: Hydrography; 4528 Oceanography: Physical: Fronts and jets; 4520 Oceanography: Physical: Eddies and mesoscale processes; KEYWORDS: water masses, subtropical front, mesoscale, chlorophyll

Citation: Pérez, F. F., M. Gilcoto, and A. F. Ríos, Large and mesoscale variability of the water masses and the deep chlorophyll maximum in the Azores Front, J. Geophys. Res., 108(C7), 3215, doi:10.1029/2000JC000360, 2003.

\section{Introduction}

[2] In this paper we use hydrographic, acoustic Doppler current profiler $(\mathrm{ADCP})$, and fluorescence data to describe large-scale $(O 1000 \mathrm{~km})$, mesoscale $(O 100 \mathrm{~km})$, and submesoscale $(O 10 \mathrm{~km})$ circulation, water mass distribution, and the chlorophyll field along the subtropical front from the Middle Atlantic Ridge (MAR) to the Madeira Islands (Figure 1). The Azores Current (AC) originates in the transition region between the Gulf Stream and the North Atlantic Current (NAC), near the southeastern Newfoundland Rise, and forms the northeastern boundary of the Sargasso Seawater [Krauss and Meincke, 1982; Gould, 1985; Klein and Siedler, 1989]. The AC crosses the MAR

Copyright 2003 by the American Geophysical Union. 0148-0227/03/2000JC000360 between $32^{\circ} \mathrm{N}$ and $37^{\circ} \mathrm{N}$, near the Oceanographer and Hayes fractures zones [Sy, 1988; Pingree et al., 1999]. Klein and Siedler [1989] have shown that the AC flows across the eastern basin at approximately $34^{\circ} \mathrm{N}$ as jetlike meandering zonal current with three main southward recirculation branches joining the westward flowing North Equatorial Current (NAC). The AC is characterized by strong temperature and salinity cross-gradients, characterizing the signature of the well known Azores Front (AF), and forms the northern boundary of the North Atlantic subtropical gyre [Käse and Siedler, 1982; Gould, 1985; Käse et al., 1985; Siedler et al., 1985; Sy, 1988; Pingree et al., 1999]. These gradients are not density compensated, thus resulting in strong geostrophic shears [Gould, 1985; Siedler et al., 1985].

[3] Two distinct bodies of water converge in the AF. Water advected from the southern flank of the NAC is 
(a)
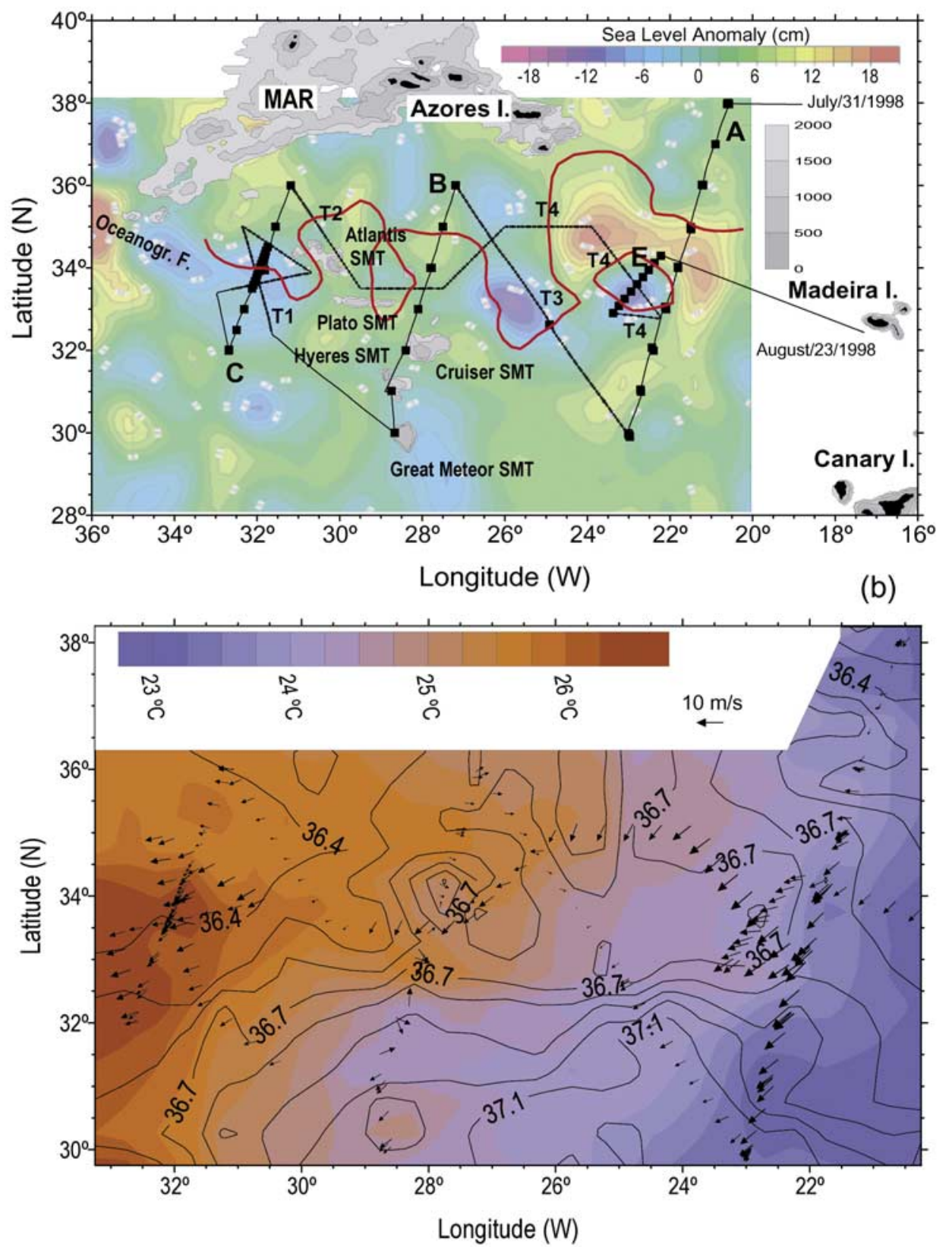

Figure 1. (a) Cruise track for "AZORES I" showing the positions of CTD stations (solid squares) and the Undulator sampling down to $150 \mathrm{~m}$ (crosses). Sea level anomaly of August 12, 1998, is also included. The red line indicates the Azores Front. (b) Sea surface salinity (isolines) and temperature $\left({ }^{\circ} \mathrm{C}\right)$. Wind direction and speed $\left(\mathrm{m} \mathrm{s}^{-1}\right)$ are represented by direction and relative magnitude of the arrows, respectively.

located on the northern side [Klein and Siedler, 1989; Pollard et al., 1996], whereas water with a higher salinity and temperature and lower dissolved oxygen concentration, originating from the inner region of the subtropical gyre, is found on the southern side [Pollard and $\mathrm{Pu}, 1$ 1985]. A temperature and salinity step of the order $2^{\circ} \mathrm{C}$ and 0.3 can be observed between 100 and 400 dbar within this narrow (about $20 \mathrm{~km}$ wide) frontal zone [Gould, 1985; Stramma and Müller, 1989; Pingree et al., 1999]. A characteristic feature often found above $200 \mathrm{dbar}$ toward the southeast of the front is a pycnostad $\left(17^{\circ}-19^{\circ} \mathrm{C}\right.$ and $\left.36.5-36.7\right)$ corresponding to the lightest subtropical mode of Eastern North Atlantic Central Water (ENACW) and labeled as Madeira Mode Water (MMW) by Siedler et al. [1987]. The $18^{\circ} \mathrm{C}$ thermostat corresponding to Sargasso Seawater (SSW) is absent east of $30^{\circ} \mathrm{W}$ [Gould, 1985]. However, Ríos et al. [1992] found only Western North Atlantic Central Water (WNACW) in the core of AC along the $23^{\circ} \mathrm{W}$ section. Fiúza and Halpern [1982] also found saltier subtropical mode water in the Canary Basin. Emery and Meincke [1986] assigned this water ENACW, extending within a long $\theta-\mathrm{S}$ segment $\left(8^{\circ}-23^{\circ} \mathrm{C}\right.$ and $\left.35.2-36.7\right)$. 
[4] Independent evidence of seasonal variation in the northern part of the gyre, namely the southward shift of the $\mathrm{AC}$ and the related AF in summer, has been reported [Siedler et al., 1985; Stramma and Isemer, 1988; Stramma and Siedler, 1988]. Upon investigating the meridional thermal fluxes in the eastern North Atlantic, these workers located the AC south of $35^{\circ} \mathrm{N}$ in summer. Furthermore, from April to September when the subtropical gyre is stronger west of the Canary Islands, southward transport near the African coast is greater than during October to March. Stramma and Siedler [1988] reported that the zonal axis of the AC shifts $2^{\circ} \mathrm{S}$ in summer, with a larger west-east and smaller north-south extension of the gyre in summer than winter. In addition, Klein and Siedler [1989] found that the current narrows in summer and moves farther south with a strengthening of lateral temperature and salinity gradients in the AF.

[5] Mesoscale circulation in the Azores-Madeira region is dominated by the meandering of the $\mathrm{AF}$ and associated eddies [Käse and Siedler, 1982; Käse et al., 1985; Gould, 1985; Pingree, 1997]. Numerical and observational evidence suggests that part of the mesoscale variability may result from the baroclinic instability of the $\mathrm{AC}$ created by the strong meridional asymmetry of thermohaline field [Käse et al., 1985; Kielmann and Käse, 1987; Alves and Colin de Verdière, 1999; Lévy et al., 2001]. The jet, and corresponding mesoscale turbulence, has a strong meridional asymmetry due to the pronounced sloped thermocline that usually generates anticyclonic meanders and eddies to the north and cyclonic meanders and eddies to the south [Pingree and Sinha, 1998; Pingree et al., 1999; Alves and Colin de Verdière, 1999]. On the whole, however, the AC is recognized as an eastward transport band almost zonally orientated. The averaging of AF meanders produces a broader flow, identified from quasi-synoptic observations. The 0 - to $800-\mathrm{m}$ transport at $35^{\circ} \mathrm{W}$ is about $10 \mathrm{~Sv}$, which equals the results from quasi-synoptic surveys [Käse and Siedler, 1982; Käse et al., 1985]. From an objective analysis of NODC hydrological data with a $1^{\circ} \times 1^{\circ}$ spatial resolution, Alves and Colin de Verdière [1999] showed that the $\mathrm{AC}$ as an eastward jet centered on $34^{\circ} \mathrm{N}$ with an average transport of $13 \mathrm{~Sv}$. They also observed the subsurface westward flowing Azores Countercurrent (AzCC) on the northern flank of the $\mathrm{AC}$ with a mean annual transport of $2.0 \mathrm{~Sv}$ at approximately $37^{\circ} \mathrm{N}$. These findings were first mentioned explicitly by Onken [1993], although AzCC signals between 200 and $800 \mathrm{~m}$ were recorded by Klein and Siedler [1989], Stramma and Isemer [1988] and Ríos et al. [1992]. Pollard et al. [1996] noted an eastward transport between $39^{\circ} \mathrm{N}$ and $42^{\circ} \mathrm{N}$ assumed to be the northern rim of the anticyclonic gyre described by Onken [1993]. Recently, hydrography and ERS-1 altimetry combined by Cromwell et al. [1996] revealed a westward surface current at the north of the AC jet assumed to be a retroflection of the AC. Alves and Colin de Verdière [1999] reported similar countercurrents on the southern flank of the AC in summer. In addition, ALACE and drogued buoys have revealed clockwise and counterclockwise recirculation [Pingree, 1997].

[6] Fronts are generally related to sharp changes in the distribution of planktonic forms and enhanced levels of pelagic biomass and production. However, few studies have assessed the biological response in the Azores frontal zone. Fasham et al. [1985] described the factors affecting the spatial pattern of the Deep Chlorophyll Maximum (DCM) along a meander of the AC during spring 1982 between $28^{\circ} \mathrm{W}$ and $36^{\circ} \mathrm{W}$. Higher values of chlorophyll $(0.5 \mathrm{mg} \mathrm{Chl}$ $\left.\mathrm{m}^{-3}\right)$ were found on the northern side than the south $(0.3 \mathrm{mg}$

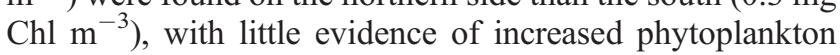
biomass associated with the front. However, Fernández and Pingree [1996] observed a close linkage between AC physical features and high levels of chlorophyll $(0.3 \mathrm{mg}$

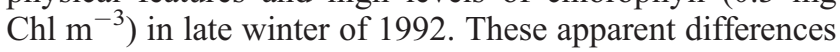
could be related to temporal and spatial changes in a very active front. All biological studies were mainly circumscribed to the springtime. In October, Pingree et al. [1999] measured about $0.3 \mu \mathrm{g} \mathrm{kg}^{-1}$ of chlorophyll.

[7] This work describes the coupling between the physical and biological fields on both sides of the AF between the MAR and Madeira Islands during summer, considering both large scale and mesoscale. Several hypotheses will be tested: first, whether large-scale mass variability is absent, as some papers have established, and if the $\mathrm{AC}$ and the $\mathrm{AF}$ have the same oceanographic signature at short spatial scales; second, whether chlorophyll concentrations are low and present low spatial variability in summer as would be expected from previous studies in oligotrophic systems, or whether the chlorophyll field responds to the mesoscale activity as recent models in this area have established; and finally, the factors affecting the baroclinic stability described in previous models are discussed on the basis of our observations.

[8] We present the "physical framework" of the largescale distribution of transport, thermohaline properties, and chlorophyll (section 3.1). The following section will be dedicated to water mass classification in order to understand the modification of the water transported by the $\mathrm{AC}$ (section 3.2). Furthermore, a small-scale study of water masses will allow the $\mathrm{AF}$ and $\mathrm{AC}$ to be distinguished and the best tracer of the AF for selected levels to be defined (section 3.3). The following mesoscale description depicts a downstream decrease of the chlorophyll concentration along the AC revealing a spatial change in the physical and biological fields (section 3.4). Finally, we describe the cyclonic structural interactions of the chlorophyll concentrations (section 3.5).

\section{Methods}

[9] The AZORES I cruise was carried out in August 1998 on board the BIO Hesperides. The survey comprised three latitudinal large-scale sections (A, B, and C) at nominal longitudes of $22^{\circ} \mathrm{W}, 28^{\circ} \mathrm{W}$, and $32^{\circ} \mathrm{W}$, along with two mesoscale sections centered at $32^{\circ} \mathrm{W}$ and $23^{\circ} \mathrm{W}$ with CTD-fluorometer stations (Figure 1). Recent cruises in the area [Pingree, 1997] determined the cruise strategy, and each main section was sampled every $1^{\circ}$ of latitude from $30^{\circ} \mathrm{N}$ to $36^{\circ} \mathrm{N}-38^{\circ} \mathrm{N}$ with the exception of section $\mathrm{C}$, which was sampled from $32^{\circ} \mathrm{N}$ to $36^{\circ} \mathrm{N}$ every $1 / 2^{\circ}$ and from $33.5^{\circ} \mathrm{N}$ to $34.5^{\circ} \mathrm{N}$ every $5^{\prime}$. A deep CTD cast to the bottom was performed at each station. Sea Level Anomaly (SLA) maps (July 29 and August 12) were received from CLS (Centre Laboratoire Spatial of the European Union's Environment and Climate Project) on the ship during the cruise and were used to define the mesoscale sections and Undulator trawls. 
[10] A General Oceanic CTD (Mark III WOCE Single) was attached to a rosette with 24 Niskin bottles. A transmissometer, altimeter, and fluorometer were also deployed with the CTD rosette. Water samples for chemical analyses were taken with 12-L Niskin bottles at different levels throughout the water column. In the upper $200 \mathrm{~m}$, six levels were selected according to the fluorescence profile. Bottles were closed at the DCM and approximately 15-20 $\mathrm{m}$ above and below, with further bottle sampling at the surface layer and the thermocline (about 30-60 m). Another additional level was selected between the thermocline and the DCM.

[11] Continuous underway measurement of surface temperature, salinity, and fluorescence was achieved with a deck-mounted SBE thermosalinograph and a Turner fluorometer. The thermosalinograph was calibrated by comparison with CTD data. The surface fluorescence measurements were practically zero and constant $\left(<0.05 \mathrm{mg} \mathrm{Chl} \mathrm{m}^{-3}\right)$ along the entire Azores I cruise track.

[12] An Undulator towed vehicle (Nv-Shuttle, Chelsea Instruments) was occasionally deployed transit between distant stations (Figure 1). The Undulator was equipped with a CTD probe, fluorometer and transmissometer. With a ship speed about 10 knots the instrument drops to 150 dbar and periodically raises close to the surface at 5-min intervals $(1.5 \mathrm{~km})$. The temperature and salinity sensors were calibrated against the calibrated thermosalinograph data.

[13] A ship-mounted RDI narrow band $(150 \mathrm{kHz})$ ADCP was used throughout the cruise to derive the current vectors in the upper $250 \mathrm{dbar}$ of the water column. ADCP data were merged with Global Position System data (GPS) [Dixon, 1991] and 3D-ASTECH attitude data [Griffiths, 1994; King and Cooper, 1993] to give absolute water velocity profiles.

[14] A set of 50 seawater samples were taken at selected depths for salinity measurements in order to test the conductivity probe of CTD. Salinity analyses were made with an Autosal $8400 \mathrm{~A}$ at $24^{\circ} \mathrm{C}$ in a temperature controlled laboratory. The average difference between the salinity measured by the CTD and under laboratory conditions was $0.008 \pm 0.008$, with the CTD salinity tending toward the lower values.

[15] For deriving Chlorophyll $a$ concentrations from the fluorescence data, $250-\mathrm{mL}$ seawater samples were filtered through Millipore GF/F filter using a glass filtration system (filtrate pressure $<0.3 \mathrm{~kg} \mathrm{~cm}^{-2}$ ). The filters were subsequently frozen and chlorophyll a extracted with $90 \%$ acetone. The fluorescence of each extract was measured using a Turner Design $10000 \mathrm{R}$ fluorometer [Yentsch and Menzel, 1963], calibrated with a sample of Phaeocystis tricornutum. A total of 257 chlorophyll samples from between the surface and $200 \mathrm{~m}$ were used to calibrate the fluorometer attached to the CTD and the deck-mounted underway fluorometer. The fluorescence readings from the CTD up-cast were calibrated against fluorimetrically estimated chlorophyll $a$ concentrations. A very good correlation was found $\left(\mathrm{r}^{2}=0.93\right)$, and fluorescence readings $(\mathrm{FR})$ were transformed to chlorophyll $a\left(\mathrm{mg} \mathrm{Chl} \mathrm{m}{ }^{-3}\right)$ with the corresponding linear equation (Chl $a=1.53 \times \mathrm{FR}-$ 0.02 ). The Undulator fluorometer was calibrated by comparison of the highest values observed in section $\mathrm{T} 1$ (approximately $33.5^{\circ} \mathrm{N}-34^{\circ} \mathrm{N}$; Figure 1), with CTD fluorometer data at section $\mathrm{C}$.

\section{Results}

\subsection{Large-Scale Variability}

[16] The typical large-scale feature that characterizes the sea surface salinity (SSS) and temperature (SST) fields in the subtropics is a meridional gradient with a northward decrease of the thermohaline values. During the Azores I cruise, both the SST and SSS fields showed a significant zonal variability (Figure 1b) extended over the typical pattern. From $30^{\circ} \mathrm{W}$ to $22^{\circ} \mathrm{W}$ a relatively narrow SSS meridional gradient along $32^{\circ} \mathrm{N}-33^{\circ} \mathrm{N}$ shows the surface signal of the AF. This feature separates areas with greatest SSS to the southeast from the northern zone, where several mesoscale structures can be detected. These structures are well identified by SSS and SLA maxima and minima (Figure 1 ) at $34^{\circ} \mathrm{N}-28^{\circ} \mathrm{W}$ and $33.5^{\circ} \mathrm{N}-23^{\circ} \mathrm{W}$, respectively. Furthermore, an eastward increase of SSS was observed with the minimum located to the west of $30^{\circ} \mathrm{W}$, where warm surface waters with the highest SST and transported by the $\mathrm{AC}$ entered the area. These warm waters extended eastward mainly to the north of the SSS gradient. On the opposite side, relatively cold waters from the Northwest African upwelling region penetrate via the southeast, conforming to an anomalous SST picture where the meridional gradient is opposite to the typical large-scale pattern usually observed [Stramma and Müller, 1989; Pingree, 1997]. A monthly atlas of SST spanning 3 years obtained from infrared remote sensing (P. Oliveira et al., personal communication, 1996) revealed that this anomalous SST pattern was repeatedly recurrent during summer months. The area is affected by large-scale seasonal heating, which diminishes northward. Nevertheless, other processes such as evaporation and advection, enhanced by prevailing northerlies, are responsible for the SST and SSS fields. The strong and persistent trade winds generated a zone around $30^{\circ} \mathrm{N}-35^{\circ} \mathrm{N}$ and $25^{\circ} \mathrm{W}$ with excess of evaporation and heat loss [Schmitt et al., 1989; Marshall et al., 1993], contributing to an increase of salinity and density (loss of buoyancy) along the southern side of the AC.

[17] The temperature (density) field of the upper 350 dbar (Figure 2) shows a thermocline (pycnocline) located between 35 and $70 \mathrm{dbar}$. The thermocline was stronger to the west (section $\mathrm{C}$ ) and to the north due to the SST pattern. A distinct mixed layer in the upper $50-70$ dbar is observed at the southern end of sections $\mathrm{A}$ and $\mathrm{B}$. Comparing sections $\mathrm{A}$ and $\mathrm{B}$, a slight eastward density increase can be noted where the density of the mixed layer was maximum. Below the thermocline in section $\mathrm{C}$, a thermostad of $17^{\circ}-18^{\circ} \mathrm{C}$ centered at $33^{\circ} \mathrm{N}$ was identified as SSW [Gould, 1985]. On the southern side of sections A and $\mathrm{B}$ at $32^{\circ} \mathrm{N}$, the thermostad below the thermocline was slightly warmer and probably linked to MMW advection. Along section $\mathrm{C}$ from $33.5^{\circ} \mathrm{N}$ to $34.5^{\circ} \mathrm{N}$, the $\mathrm{AC}$ was clearly distinguished by the northward sloping of the $16^{\circ} \mathrm{C}$ isotherm and 26.7 isopycnal at approximately 160 and 145 dbar, respectively. Along section B the same isolines locating the position of the $\mathrm{AC}$ presented maximum slopes between $34^{\circ} \mathrm{N}$ and $35^{\circ} \mathrm{N}$. However, it is likely that an additional eastward current was located between $31^{\circ} \mathrm{N}$ and 


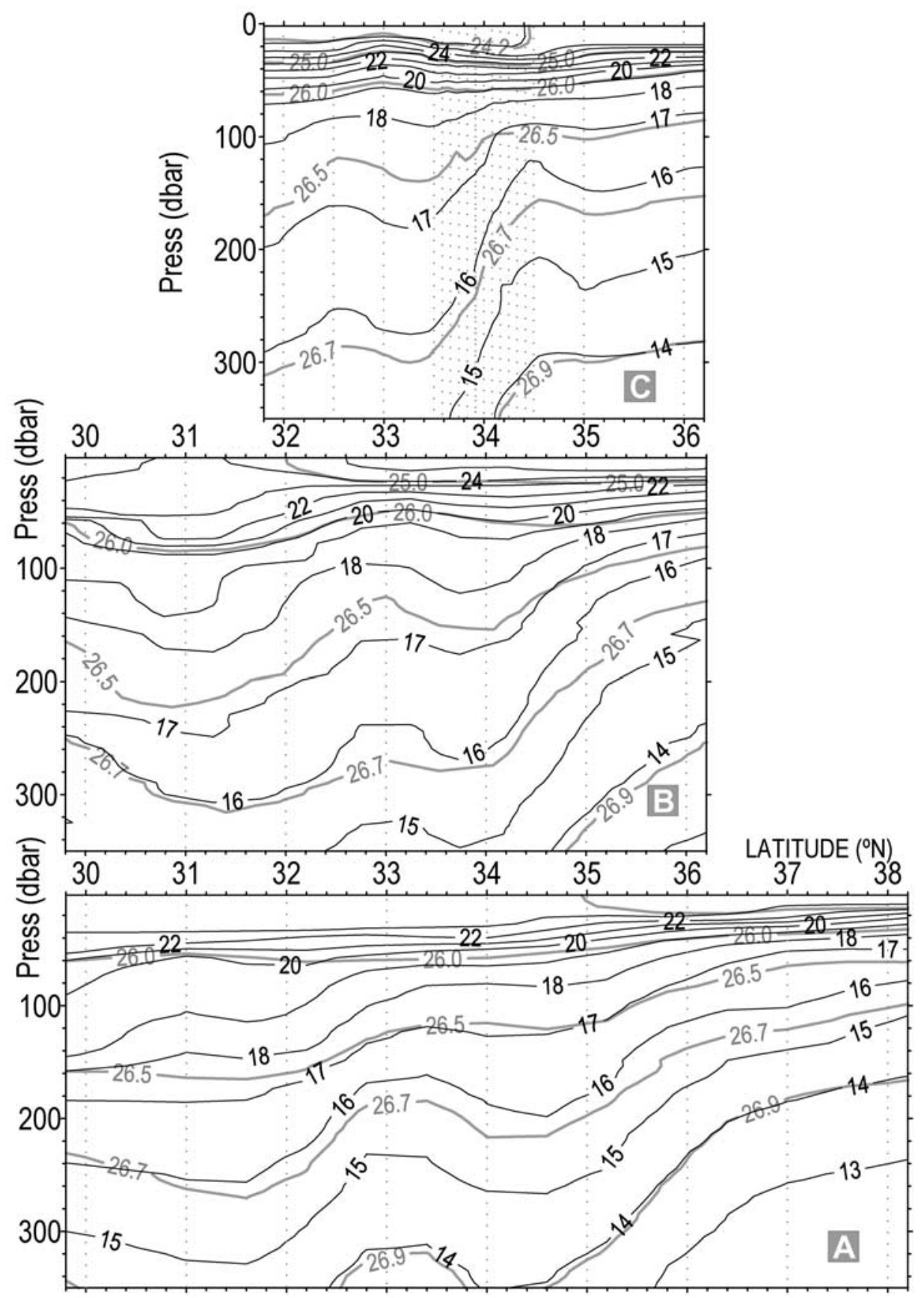

Figure 2. Vertical distributions of temperature (black line) and density (shaded line) along sections A $\left(\sim 22^{\circ} \mathrm{W}\right), \mathrm{B}\left(\sim 28^{\circ} \mathrm{W}\right)$, and $\mathrm{C}\left(\sim 32^{\circ} \mathrm{W}\right)$.

$33^{\circ} \mathrm{N}$. Along section $\mathrm{A}$ the slopes of these isolines were very similar between $32^{\circ} \mathrm{N}-33^{\circ} \mathrm{N}$ and $35^{\circ} \mathrm{N}-36^{\circ} \mathrm{N}$. However, in view of the fact that the $16^{\circ} \mathrm{C}$ isotherm crossed the 200-dbar horizon at these latitudes, the AC was located between $32^{\circ} \mathrm{N}$ and $33^{\circ} \mathrm{N}$ [Gould, 1985].

[18] The geostrophic currents were obtained from the density field using $2000 \mathrm{dbar}$ as the surface reference [Stramma and Siedler, 1988; Gould, 1985; Pingree, 1997; Paillet and Mercier, 1997]. A strong geostrophic current (AC) was found in the west, section $\mathrm{C}$, with a maximum of $25 \mathrm{~cm} \mathrm{~s}^{-1}$ at 140 dbar (Figure 3). Two weaker countercurrents were located on either side of the AC. Furthermore, a westward surface countercurrent was observed in the upper thermocline above the AC, developing a strong shear in the pycnocline and transporting the warm waters (Figure 1b). This countercurrent may be associated with strong easterly winds (Figure 1b). Owing to the presence of this surface countercurrent, the surface signal of the AC was shifted southward about $80 \mathrm{~km}$. In section C, the total eastward transport of the AC in the upper 2000 dbar from $33^{\circ} \mathrm{N}$ to $34.4^{\circ} \mathrm{N}$ was $16.1 \mathrm{~Sv}$, while the AzCC transported $5.3 \mathrm{~Sv}$ westward from $34.4^{\circ} \mathrm{N}$ to $36^{\circ} \mathrm{N}$. A net 


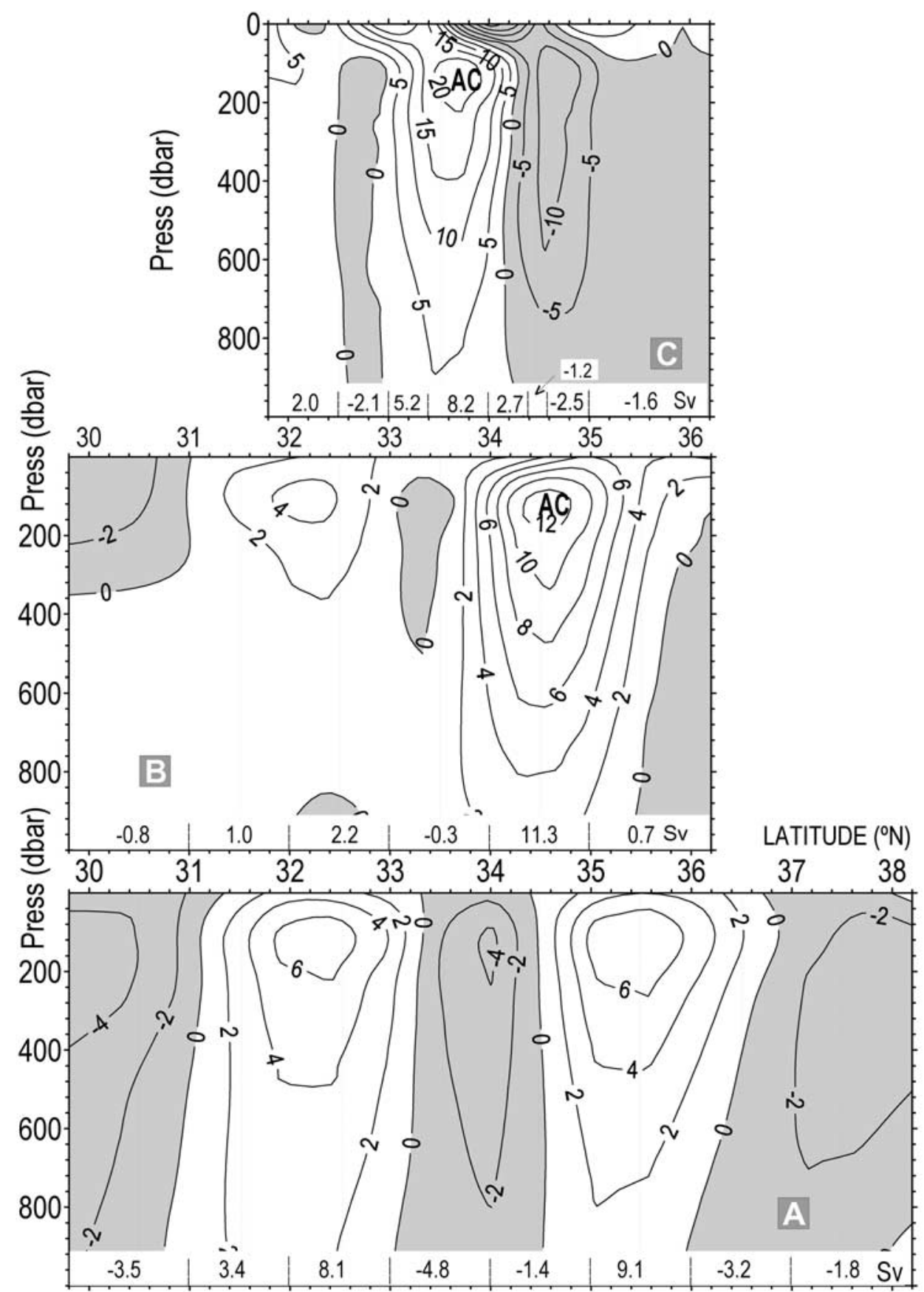

Figure 3. Geostrophic velocity in $\mathrm{cm} \mathrm{s}^{-1}$ (positive to the east) in the vertical sections $\mathrm{A}\left(\sim 22^{\circ} \mathrm{W}\right), \mathrm{B}$ $\left(\sim 28^{\circ} \mathrm{W}\right)$, and $\mathrm{C}\left(\sim 32^{\circ} \mathrm{W}\right)$. The reference layer is $2000 \mathrm{dbar}$. Water transport (Sv) down to $2000 \mathrm{dbar}$ is indicated at the bottom of each section.

eastward transport of $10.7 \mathrm{~Sv}$ was estimated along section C $\left(32^{\circ} \mathrm{N}-36^{\circ} \mathrm{N}\right)$. These results agree well with previous estimations. The first scheme of water transport for the North Atlantic included an AC water transport of $10 \mathrm{~Sv}$ [Dietrich et al., 1975]. Klein and Siedler [1989] calculated an $\mathrm{AC}$ transport of $10 \mathrm{~Sv}$ in the upper $800 \mathrm{~m}$ across the MAR south of the Azores between $32^{\circ} \mathrm{N}$ and $36^{\circ} \mathrm{N}$ (analogous to $75 \%$ of the transport between surface and 2000 dbar). At approximately $34^{\circ} \mathrm{N}$ and $34^{\circ} \mathrm{W}$, Gould [1985] described the $\mathrm{AC}$ as a 50-km-wide eddy-like structure, with maximum currents of $35 \mathrm{~cm} \mathrm{~s}^{-1}$ and $13 \mathrm{~Sv}$ of water transport above 2000 dbar. From thermohaline data along $33^{\circ} \mathrm{W}$, Stramma and Müller [1989] estimated an AC transport to the east of about $10 \mathrm{~Sv}$ between the surface and $800 \mathrm{dbar}$, with surface velocities exceeding $10 \mathrm{~cm} \mathrm{~s}^{-1}$ between $33.2^{\circ} \mathrm{N}$ and $35^{\circ} \mathrm{N}$.

[19] In section $\mathrm{B}$, the $\mathrm{AC}$ was located between $34^{\circ} \mathrm{N}$ and $35^{\circ} \mathrm{N}$ with a maximum current of $12 \mathrm{~cm} \mathrm{~s}^{-1}$ and an eastward transport of $11.3 \mathrm{~Sv}$, approximately $30 \%$ lower than observed in section C. A weak eastward current computed 


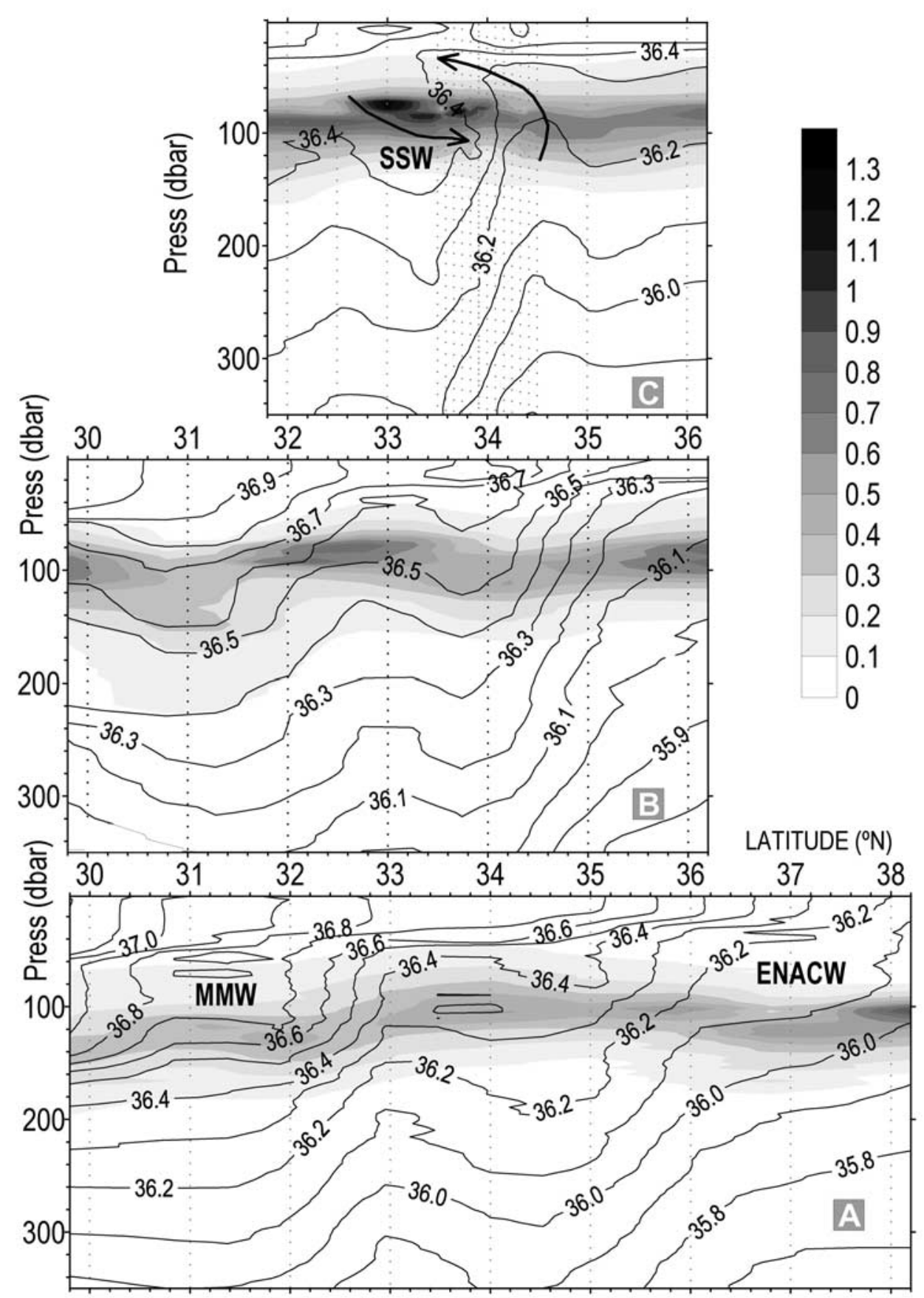

Figure 4. Distribution of salinity and chlorophyll (in gray scale) in the vertical sections $\mathrm{A}\left(\sim 22^{\circ} \mathrm{W}\right), \mathrm{B}$ $\left(\sim 28^{\circ} \mathrm{W}\right)$, and $\mathrm{C}\left(\sim 32^{\circ} \mathrm{W}\right)$. SSW, Sea Sargasso Water; MMW, Madeira Mode Water; ENACW, Eastern North Atlantic Central Water.

between $31^{\circ} \mathrm{N}$ and $33^{\circ} \mathrm{N}$ with a net transport of $3.2 \mathrm{~Sv}$ may be due to mesoscale dynamics. The very weak countercurrents observed were probably owing to the northward shift of the AC system. The total eastward transport of 14.1 Sv along section $\mathrm{B}$ is higher than the $10 \mathrm{~Sv}$ from previous estimations [Saunders, 1982]. Stramma [1984] obtained a net average transport of $11 \mathrm{~Sv}$, possibly attributable to a northward shift of the AC and AzCC. However, several authors noted high water transport arising from mesoscale features. Käse et al. [1985] reported an eastward
AC transport of $19 \mathrm{~Sv}$ relative to 1400 dbar in the range $100-800$ between $28^{\circ} \mathrm{N}$ and $35^{\circ} \mathrm{N}$ along $26^{\circ} 30^{\prime} \mathrm{W}$. In addition, Pingree [1997] gave AC transport values of $26 \mathrm{~Sv}$ for the same location between the surface and $2000 \mathrm{dbar}$.

[20] Two similar geostrophic currents, centered at $32.5^{\circ} \mathrm{N}$ and $35.5^{\circ} \mathrm{N}$, were calculated for section $\mathrm{A}$, with a maximum current of about $6 \mathrm{~cm} \mathrm{~s}^{-1}$ at $150 \mathrm{dbar}$, representing an eastward transport of 11.5 and $9.1 \mathrm{~Sv}$, respectively. The net eastward transport was $5.9 \mathrm{~Sv}$ due to three westward countercurrents and mesoscale activity (Figure 1a). In 
summer, the AF had a larger east-west and smaller northsouth extension [Stramma and Siedler, 1988], increasing the eastward transport due to contributions from the southern branch of North Atlantic Current [Paillet and Mercier, 1997]. Alves and Colin de Verdière [1999] described the seasonal variability of the AC from a 50-year data set from the National Oceanic Data Center. They calculated an average eastward transport of $12.1 \mathrm{~Sv}$ for the AC between $25^{\circ} \mathrm{W}$ and $35^{\circ} \mathrm{W}$, and a westward contribution of $2.2 \mathrm{~Sv}$ for the $\mathrm{AzCC}$ at approximately $37^{\circ} \mathrm{N}$.

[21] The saline field (Figure 4) shows more clearly the same physical features as those traced by density and temperature. In the western section, the AC core (140 dbar) transports seawater of 36.4 and $17.6^{\circ} \mathrm{C}$, whose characteristics are very similar to those of SSW, $17.9 \pm 0.3^{\circ} \mathrm{C}, 36.5 \pm$ 0.1 , and $\sigma_{\theta}=26.4$ [Talley and Raymer, 1982]. The isohalines below 36.4 were practically vertical in the front, and the 36.2 isohaline raises $180 \mathrm{dbar}$ from $33.5^{\circ} \mathrm{N}$ to $34^{\circ} \mathrm{N}$. The isohalines in the core of the AC appear to depict water elevation (downwelling) on the north (south) side of the AC. In section B the AC was clearly characterized by the strong northward elevation (about $150 \mathrm{dbar}$ ) of isohalines from 36.1 to $36.5\left(34^{\circ} \mathrm{N}\right.$ to $\left.35^{\circ} \mathrm{N}\right)$. The upper layer south of the AC experiences a saline increase at the same latitude compared to the upper layer south of the AF in section $\mathrm{C}$. In section A, two halostads below the mixed layer could be distinguished. Between $31^{\circ} \mathrm{N}$ and $32^{\circ} \mathrm{N}$ a halostad of 36.75 traces the presence of MMW [Siedler et al., 1987], whereas between $36^{\circ} \mathrm{N}$ and $38^{\circ} \mathrm{N}$ a less saline halostad of 36.15 with temperature $16^{\circ}-17^{\circ} \mathrm{C}$ are the saline modes of ENACW [Fiúza and Halpern, 1982; Fiúza, 1984; Ríos et al., 1992]. The slopes of isohalines in the three sections were higher than the respective isotherm and isopycnal slopes, implying that salinity was the best tracer of the main features of the $\mathrm{AC} / \mathrm{AF}$ for two reasons. First, the horizontal gradients of $\theta / \mathrm{S}$ properties are partially compensated in density, and second, the down penetration of seasonal heating mitigates the horizontal thermal gradients.

[22] The chlorophyll field shows the typical situation of oligotrophic systems over the whole area (Figure 4). The seawater in the upper layer above the thermocline had very low chlorophyll concentrations $\left(<0.1 \mathrm{mg} \mathrm{Chl} \mathrm{m}^{-3}\right)$. Below the thermocline a DCM was present, with levels ranging from 0.3 to $1.3 \mathrm{mg} \mathrm{Chl} \mathrm{m}{ }^{-3}$. The maximum values appear to be associated with the $\mathrm{AC}$, at the southern edge of section $\mathrm{C}$ between 70 and 90 dbar. To the east, the DCM became weaker with concentrations around $0.7 \mathrm{mg} \mathrm{Chl} \mathrm{m}^{-3}$, these being the maximum values of section $\mathrm{B}$ above $100 \mathrm{dbar}$. A further two maxima were found at either end of section $B$ at approximately $100 \mathrm{~m}$ depth. Along section A, the chlorophyll maximum was recorded at the northern end and associated with the cold and less saline water from the east (Figure 3a). The depth of the DCM along section A was below 100 dbar, deepening to the south mainly after crossing $32^{\circ} \mathrm{N}$, and reaching $140 \mathrm{dbar}$ depth at $30^{\circ} \mathrm{N}$. The DCM values also showed the same spatial pattern, being lower than $0.4 \mathrm{mg} \mathrm{Chl} \mathrm{m}^{-3}$ south of $32^{\circ} \mathrm{N}$. From the 72 CTD fluorometer profiles a significant relationship was obtained between depth and concentration at the DCM $(\mathrm{r}=0.75 \mathrm{n}=72, \mathrm{p}<0.001)$, and also between chlorophyll concentration and $\operatorname{SST}(\mathrm{r}=+0.67 \mathrm{n}=72, \mathrm{p}<0.001)$. However, there was no significant correlation between chlorophyll concentration and temperature at the DCM $(\mathrm{r}=+0.12, \mathrm{p}>0.1)$.

\subsection{Large-Scale and Mesoscale Thermohaline Characteristics of the $\mathbf{A F}$}

[23] Compared to the North Equatorial Current, the AC is frequently associated with a front where no major changes in water mass occur across it, and the structure of the density field is very similar to that of the temperature and salinity fields [Müller and Siedler, 1992]. However, as described above, both fields displayed substantial variability along the isopycnal surfaces in the upper $250 \mathrm{dbar}$, implying a change of water masses along the $\mathrm{AC} / \mathrm{AF}$. If the contrasting $\theta / \mathrm{S}$ properties of the water masses on each side of the AF are clearly delimited, a precise criterion can be employed for accurately locating the AF in mesoscale studies. The $\theta / \mathrm{S}$ profiles of section $\mathrm{C}$ (Figure $5 \mathrm{c}$ ) were used initially to determine the criterion since the $\mathrm{AC}$ was strong and the stations were carried out every $5 \mathrm{~nm}$ from $33.5^{\circ} \mathrm{N}$ to $34.5^{\circ} \mathrm{N}$. The criterion was tested with the $\theta / \mathrm{S}$ profiles of sections A and B (Figures 5a and 5b). Only the upper part of Central Waters is described because of the important meridional $\theta / \mathrm{S}$ gradients along the isopycnal. The reference lines for ENACW [Fiúza, 1984; Ríos et al., 1992], for WNACW [Iselin, 1936; Pollard et al., 1996] and the 26.2 to 26.8 isopycnal lines are also depicted in Figure 5. The $\theta / \mathrm{S}$ points at $150 \mathrm{dbar}$ for each station are indicated by the large white circles.

[24] A cluster of nine stations from $33.92^{\circ} \mathrm{N}$ to $32^{\circ} \mathrm{N}$ show similar $\theta / \mathrm{S}$ profiles with a salinity maximum of 36.45 tracing the WNACW (Figure 5c). A further cluster of four stations located between $34.25^{\circ} \mathrm{N}$ and $34.50^{\circ} \mathrm{N}$, covering a band of $20 \mathrm{~nm}$, presents an upper layer of salinity $36.17-$ 36.22 and low values of $\theta$ and $S$ at $150 \mathrm{dbar}$. The $\theta / \mathrm{S}$ profile at $34.08^{\circ} \mathrm{N}$, identified as AF, divides the two clusters. The $\mathrm{AF}$ is well characterized by the $\theta / \mathrm{S}$ profile of $34.08^{\circ} \mathrm{N}$, showing the typical interleaving between the two clusters and a segment of central water slightly apart from the $\theta / \mathrm{S}$ profiles of stations located to the south. The upper part of the $\mathrm{AF} \theta / \mathrm{S}$ profile with $\theta>18.5^{\circ} \mathrm{C}$ is close to the adjacent station located $5^{\prime}$ to the north $(\mathrm{Ns})$. Below $18.5^{\circ} \mathrm{C}$, the $\mathrm{AF} \theta / \mathrm{S}$ profile approaches the adjacent station located $5^{\prime}$ to the south (Ss). Below $17^{\circ} \mathrm{C}$ to $150 \mathrm{dbar}$, the $\theta / \mathrm{S}$ of the $\mathrm{AF}$ profile shows many fingering structures due to modification by lateral mixing of the Ss and Ns $\theta / \mathrm{S}$ profiles. Moreover, the Ns $\theta / \mathrm{S}$ profile is also slightly modified with water from the southern side of the front below $18^{\circ} \mathrm{C}$. Therefore the upper part of the AF contains water from the north, whereas between 75 and 150 dbar the AF is mixed with water from the south (WNACW). This finding agrees with the clear vertical shear between the upper and lower sides of thermocline shown by the geostrophic currents at station AF (Figure 3c). Furthermore, a north-south horizontal shear occurred at AF station. The maximum of the AC geostrophic current was located at $33.65^{\circ} \mathrm{N}$ at $140 \mathrm{dbar}$, close to the highest saline core of WNACW. According to the $\theta / \mathrm{S}$ profiles, the position of the $\mathrm{AF}$ is at the northern limit of the AC. Therefore, at the small scale, the AF and AC can be spatially distinguished, and where a strong horizontal shear occurs (Figure $3 \mathrm{c}$ ), the AF constitutes the northern boundary of the AC. With respect to water masses, the AF was only $10 \mathrm{~nm}$ wide, and well characterized by the $\theta / \mathrm{S}$ point of 

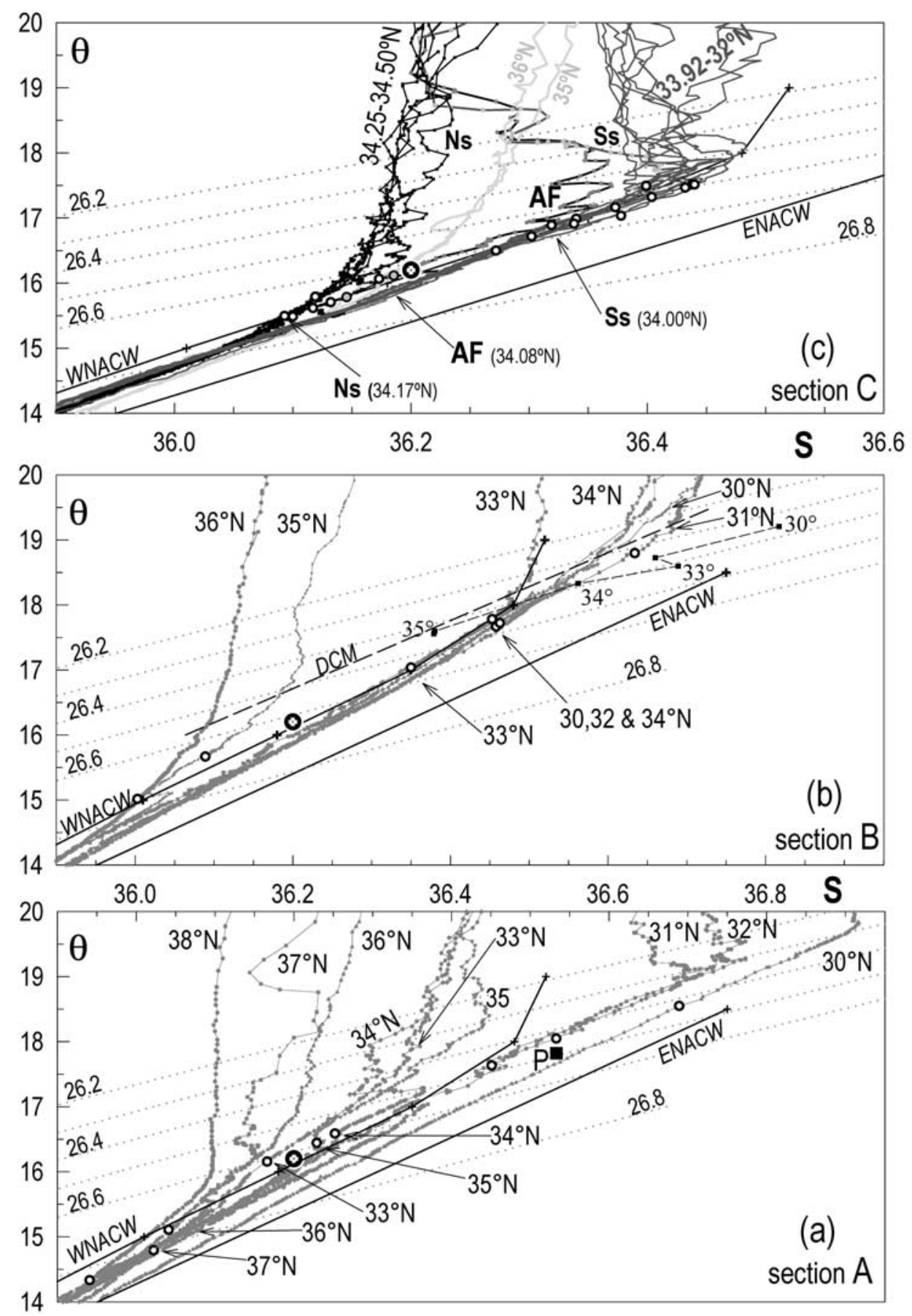

Figure 5. $\theta$-S diagrams for stations in Sections A, B, and C (one point per dbar). The reference lines for WNACW [Iselin, 1936; Pollard et al., 1996] and ENACW [Fiúza, 1984; Ríos et al., 1992] are superimposed. The density levels are indicated by dotted lines. The 150-dbar horizon at each station is marked by open points. The white cross represents $\theta-\mathrm{S}_{150}$ of the Azores Front (AF). The dashed line represents the $\theta-\mathrm{S}$ on DCM surface.

36.2 and $16.2^{\circ} \mathrm{C}\left(\sigma_{\theta}=26.6\right)$ at $150 \mathrm{dbar}\left(\theta / \mathrm{S}_{\mathrm{AF}}\right.$, white cross in Figure 5). This criterion can be extrapolated to other levels, taking into account the good spatial correlation between salinity (temperature, except for SST) at surface, DCM, 200 and 300 dbar, with salinity (and temperature) at 150 dbar (Table 1). The AF was traced by $\theta / S$ pairs at other depths for comparisons.
[25] The $\theta / \mathrm{S}$ profiles at $35^{\circ} \mathrm{N}$ and $36^{\circ} \mathrm{N}$ along section $\mathrm{C}$ (Figure $5 \mathrm{c}$ ) were saltier than the $\theta / \mathrm{S}$ at $34.5^{\circ} \mathrm{N}$ the in upper $150 \mathrm{dbar}$. However, their $\theta / \mathrm{S}$ values at $150 \mathrm{dbar}$ were lower than $\theta / \mathrm{S}_{\mathrm{AF}}$ (open shaded circles). The upwelling on the northern side of the AF causes the doming up of isohalines (Figure $4 \mathrm{c}$ ) between $34.1^{\circ} \mathrm{N}$ and $35^{\circ} \mathrm{N}$ and forces low salinity values between 80 and 140 dbar (Figure 4c). 
Table 1. Linear Relationships of Salinity and Temperature at the Surface, DCM, 200, and 300 dbar Versus Salinity and Temperature at 150 dbar

\begin{tabular}{|c|c|c|c|c|}
\hline Level & $\theta($ Level $)$ & $r^{2}$ & S(Level) & $r^{2}$ \\
\hline Surface & $(24.29 \pm 0.7)+(0.87 \pm 0.24) \times\left(\theta_{150}-16.2\right)$ & 0.05 & $(36.59 \pm 0.01)+(1.35 \pm 0.02) \times\left(S_{150}-36.2\right)$ & 0.70 \\
\hline DCM & $(17.11 \pm 0.01)+(0.84 \pm 0.01) \times\left(\theta_{150}-16.2\right)$ & 0.94 & $(36.27 \pm 0.01)+(1.01 \pm 0.02) \times\left(\mathrm{S}_{150}-36.2\right)$ & 0.95 \\
\hline $200 \mathrm{dbar}$ & $(15.37 \pm 0.05)+(0.85 \pm 0.04) \times\left(\theta_{150}-16.2\right)$ & 0.85 & $(36.11 \pm 0.01)+(0.73 \pm 0.04) \times\left(S_{150}-36.2\right)$ & 0.83 \\
\hline $300 \mathrm{dbar}$ & $(14.20 \pm 0.07)+(0.75 \pm 0.06) \times\left(\theta_{150}-16.2\right)$ & 0.76 & $(35.93 \pm 0.01)+(0.75 \pm 0.05) \times\left(\mathrm{S}_{150}-36.2\right)$ & 0.74 \\
\hline
\end{tabular}

Additionally, a doming down can be observed on the southern side of the AF between $32.5^{\circ} \mathrm{N}$ and $33.6^{\circ} \mathrm{N}$, shaping a vertical cyclonic gyre around the core of the AC. The thermohaline variability along section $\mathrm{B}$ denoted a sharp change between $34^{\circ} \mathrm{N}$ and $35^{\circ} \mathrm{N}$ (Figure 5b). The $\theta / \mathrm{S}_{\mathrm{AF}}$ point separates the two clusters of $\theta / \mathrm{S}$ profiles. Practically all $\theta / \mathrm{S}$ profiles south of $34^{\circ} \mathrm{N}$ corresponded to WNACW between $16^{\circ} \mathrm{C}$ and $18^{\circ} \mathrm{C}$. The influence of MMW can be only observed at $31^{\circ} \mathrm{N}$ at temperatures higher than $18.5^{\circ} \mathrm{C}$. At $150 \mathrm{dbar}$, the $\theta / \mathrm{S}$ points at $30^{\circ} \mathrm{N}, 32^{\circ} \mathrm{N}$, and $34^{\circ} \mathrm{N}$ were similar and close to WNACW. Along section A, three clusters of $\theta / \mathrm{S}$ profiles show sharp changes denoting the presence of the two fronts described in the previous section. The chosen $\theta / \mathrm{S}_{\mathrm{AF}}$ point locates the two AF: one between $32^{\circ} \mathrm{N}$ and $33^{\circ} \mathrm{N}$ and the other between $35^{\circ} \mathrm{N}$ and $36^{\circ} \mathrm{N}$. The first AF is consistent with the AC located close to $32^{\circ} \mathrm{N}$ (Figure $3 \mathrm{a}$ ). An eddy (Figure 1a) centered at $33.7^{\circ} \mathrm{N}$ and $22.7^{\circ} \mathrm{W}$ created the apparent presence of another front farther north. The complex $\theta / \mathrm{S}$ variability in the central cluster in section $\mathrm{A}$ is discussed in section 3.5, where the eddy is described in more detail. The northern cluster $\left(36^{\circ} \mathrm{N}, 37^{\circ} \mathrm{N}\right.$, and $\left.38^{\circ} \mathrm{N}\right)$ is discriminated by low values of $\theta / \mathrm{S}$ properties at $150 \mathrm{dbar}\left(\theta<15^{\circ} \mathrm{C}, \mathrm{S}<36.06\right.$, and $\sigma_{\theta}>$ 26.7), thus originating a sharp change with respect to the $\theta / \mathrm{S}$ properties of the station at $35^{\circ} \mathrm{N}$.

[26] The $\theta / \mathrm{S}$ profiles of the northern clusters of sections $\mathrm{A}$ and $B$ were somewhat similar and even resemble the $\theta / \mathrm{S}$ profile of the station at $34.5^{\circ} \mathrm{N}$ in section C. In other words, the large-scale water mass variability on the northern side of the AF was low and corresponded to ENACW ( $>200$ dbar) with a quasi-uniform salinity of 36.1-36.2 in the upper seasonal layer (down to 150-200 dbar). On the other hand, the southern side of the AF shows an eastward increase of salinity mainly between the isopycnals 26.2 and 26.5. The characteristic long line that represents the saline varieties of central water in the eastern boundary is observed at $30^{\circ} \mathrm{N}$ (section A). In the upper $140 \mathrm{dbar}$ a thick layer of the saltier $(>36.85)$ and warm $\left(19.2^{\circ} \mathrm{C}\right) \mathrm{MMW}$ was observed [Siedler et al., 1987]. The $\theta / \mathrm{S}$ profiles at $31^{\circ} \mathrm{N}$ and $32^{\circ} \mathrm{N}$ are similar, showing the same density (26.4) at 150 dbar as that recorded at $30^{\circ} \mathrm{N}$. The influence of MMW is probably observed in section $\mathrm{B}$ at $31^{\circ} \mathrm{N}$ at a higher temperature than $18.5^{\circ} \mathrm{C}$. MMW outcrops between Madeira and the Canary Islands. The westward displacement of MMW is associated with numerous countercurrents [Pingree, 1997; New et al., $2001]$ and its saline signal remains along the $\theta / S$ line even at $13^{\circ} \mathrm{C}$, probably by salt fingering [Schmitt, 1981]. Pingree [1997] also found saline modes of ENACW (P in Figure 5a) at $23.5^{\circ} \mathrm{W}$ and $34.1^{\circ} \mathrm{N}$ on the southern side of the AC in late winter.

[27] In summary, the $\theta / \mathrm{S}_{\mathrm{AF}}$ point divides the $\theta / \mathrm{S}$ profiles on both sides of the AF in the three main sections, although the $\theta / \mathrm{S}$ variability denoted an eastward modification of the water mass along the southern side of AF. The use of the $16^{\circ} \mathrm{C}$ isotherm to define the $\mathrm{AF}$ at $200 \mathrm{~m}$ or the $15^{\circ} \mathrm{C}$ isotherm at $300 \mathrm{~m}$ [Gould, 1985] gives an approximate location of the AF to be about $0.5^{\circ}-0.6^{\circ} \mathrm{C}$ warmer or about 20-30 nm farther south, and close to the core of AC. Thus, for describing water masses, the classical reference is useful for locating the $\mathrm{AC}$, which is situated about $30 \mathrm{~nm}$ south of the real AF. Consequently, a more accurate discrimination between $\mathrm{AC}$ and $\mathrm{AF}$ has been made at short scale. The AF constitutes the northern edge of the $\mathrm{AC}$ where there is a sharp change in the $\theta / \mathrm{S}$ profiles.

\subsection{Mesoscale Variability of the AF and AC}

[28] In order to analyze the mesoscale variability of the $\mathrm{AF}$, data of salinity at $150 \mathrm{dbar}$ from the Undulator and CTD were collected (Figure 6a) over the mesoscale features, typically of the order $300 \mathrm{~km}$ [Kielmann and Käse, 1987; Le Traon and De Mey, 1994; Alves and Colin de Verdière, 1999]. Between temperature and salinity at 150 dbar, there was a high correlation $\left(\mathrm{r}^{2}=0.97\right)$ with a slope of $5.9 \pm 0.1$. Therefore only the $16.2^{\circ} \mathrm{C}$ isotherm is shown (Figure 6a), and almost coincides with the 36.2 isohaline. The slope is nearly twice the slope of the 26.5 isopycnal in the $\theta / \mathrm{S}$ (Figure 5), thus advocating the use of the 150 -dbar horizon versus the 26.5 isopycnal to describe the AF. The $\mathrm{AF}$ is well traced by the 36.2 isohaline, which is also shown in Figure 1a as a comparison with the bathymetry and altimetry.

[29] After crossing the MAR at the Oceanographic Fracture, the AF entered the study area at $34.08^{\circ} \mathrm{N}$ and $32^{\circ} \mathrm{W}$ (section C). It continued southeastward $\left(120^{\circ} \mathrm{T}\right)$ ahead of $30.7^{\circ} \mathrm{W}$ by $33.5^{\circ} \mathrm{N}$, turning left and configuring a large anticyclonic meander around the west flank of Atlantis SMT (Figure 1). Thereafter, the AF was directed southward, turning left and north at the Plato SMT $\left(33^{\circ} \mathrm{N}\right)$, almost closing a cyclonic meander. The AF then passed section $\mathrm{B}$ at $34.8^{\circ} \mathrm{N}$ exiting the seamount chains to deep waters (sound $>4.5 \mathrm{~km}$ ) and later experiencing a southward shift of $2.5^{\circ}$ until $32^{\circ} \mathrm{N}-26^{\circ} \mathrm{W}$, due to southerly spreading of a tongue of cold and less saline water. This cold and less saline water seems to progress southward to $32.5^{\circ} \mathrm{N}$ and $25^{\circ} \mathrm{W}$, and also eastward to form the strong cold cyclonic eddy centered at $33.7^{\circ} \mathrm{N}$ and $22.7^{\circ} \mathrm{W}$, thus isolating a warm anticyclonic eddy at $35^{\circ} \mathrm{N} 24^{\circ} \mathrm{W}$.

[30] The saline field at $150 \mathrm{dbar}$ describes a total of three cyclonic meanders $\left(31^{\circ} \mathrm{W}, 29^{\circ} \mathrm{W}\right.$, and $\left.25.5^{\circ} \mathrm{W}\right)$ and the cyclonic eddy. In addition, the two anticyclonic meanders $\left(30^{\circ} \mathrm{W}\right.$ and $\left.28^{\circ} \mathrm{W}\right)$ and the anticyclonic eddy at $24^{\circ} \mathrm{W}$ showed were broader than their cyclonic counterparts. Eastward of $29^{\circ} \mathrm{W}$, the transversal saline gradient became stronger due to the increasing salinity on the southern side of the AF. Furthermore, the southward spreading of the less saline (cold) water in the cyclonic meanders increases this 

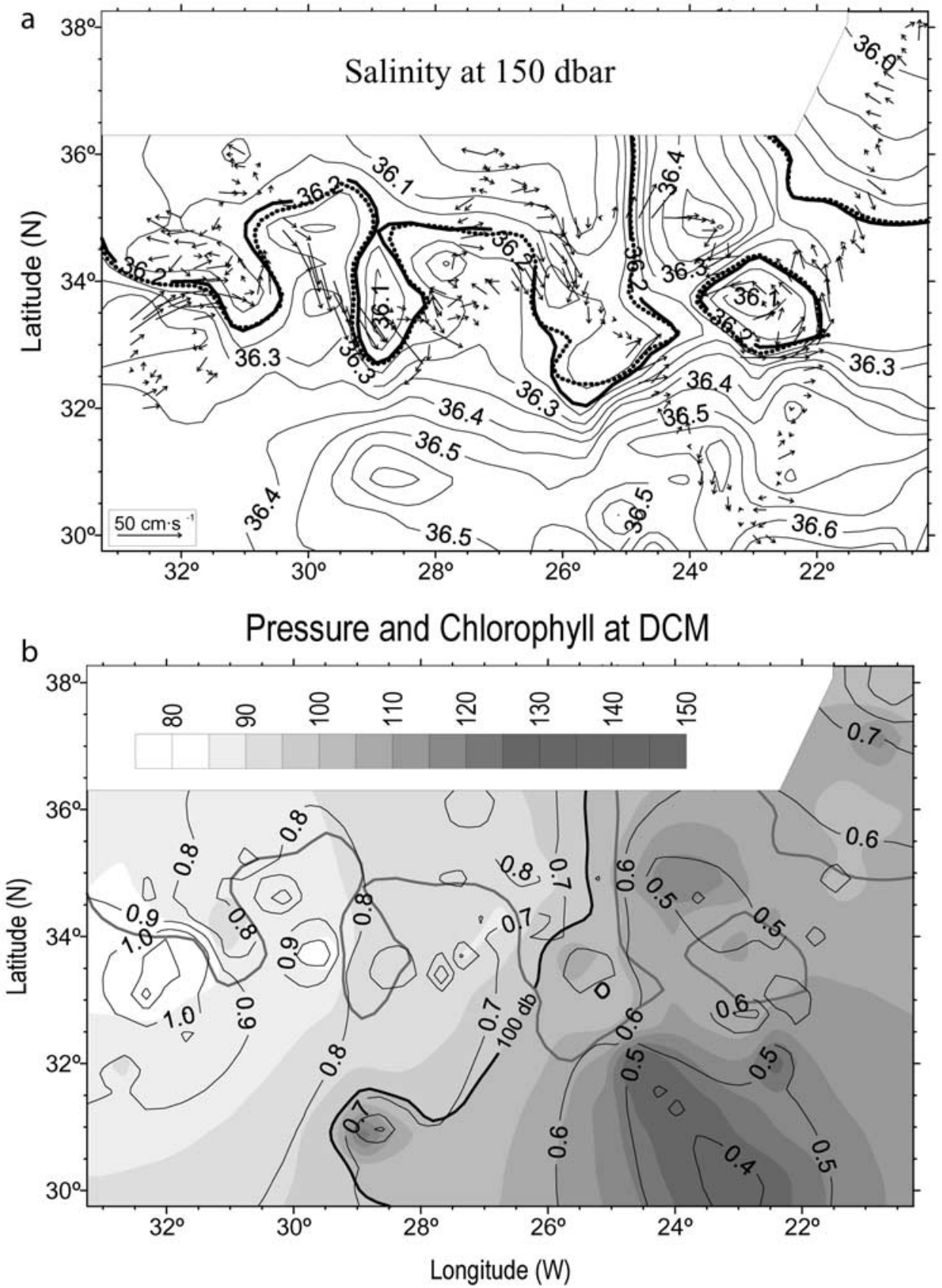

Figure 6. (a) Distribution of salinity at the 150-dbar surface. The thick black line traces the AF (Azores Front), and the dotted line traces the $16.2^{\circ} \mathrm{C}$ isotherm. Arrows show the averaged currents measured by the ADCP. (b) Distribution of chlorophyll $a\left(\mathrm{mg} \mathrm{Chl} \mathrm{m}^{-3}\right)$ at the DCM. The pressure (dbar) at the DCM was indicated in gray scale. The thick shaded line traces the AF.

transversal gradient. The meanders seem to advance to the east to form two detached cyclonic and anticyclonic eddies. The altimetry map (Figure 1a) is well paralleled with the saline field at $150 \mathrm{dbar}$. The SLA minima at $23^{\circ} \mathrm{W}, 25.5^{\circ} \mathrm{W}$, and $29^{\circ} \mathrm{W}$ and maxima at $24^{\circ} \mathrm{W}, 28^{\circ} \mathrm{W}$, and $30^{\circ} \mathrm{W}$ were situated close to the cyclonic and anticyclonic structures, respectively. In the altimeter map, the clearest feature was the tripole-like structures identifying meanders or eddies. The minimum of SLA at $33^{\circ} \mathrm{W}$ was not identified as a mesoscale structure when several sections were performed in order to detect it.
[31] The AF was located above the established northern limit of the AC. Moreover, the AC is mainly expected to be situated on the southern (or right) side of the AF. The processed ADCP data averaged geographically $\left(0.12^{\circ}\right.$ bins $)$ and vertically down to $250 \mathrm{dbar}$ and describe the mean velocity of the upper layer (Figure 6a). This dynamic field is consistent with the thermohaline field at 150 dbar. Strong and persistent currents of about $35 \mathrm{~cm} \mathrm{~s}^{-1}$ were observed slightly to the south of the AF at $32^{\circ} \mathrm{W}$. The strong eastward currents, approximately $30 \mathrm{~cm} \mathrm{~s}^{-1}$, at $31^{\circ} \mathrm{W}, 27^{\circ} \mathrm{W}, 25^{\circ} \mathrm{W}$, and $23^{\circ} \mathrm{W}$ seem to confirm the meandering of $\mathrm{AC}$ in this 

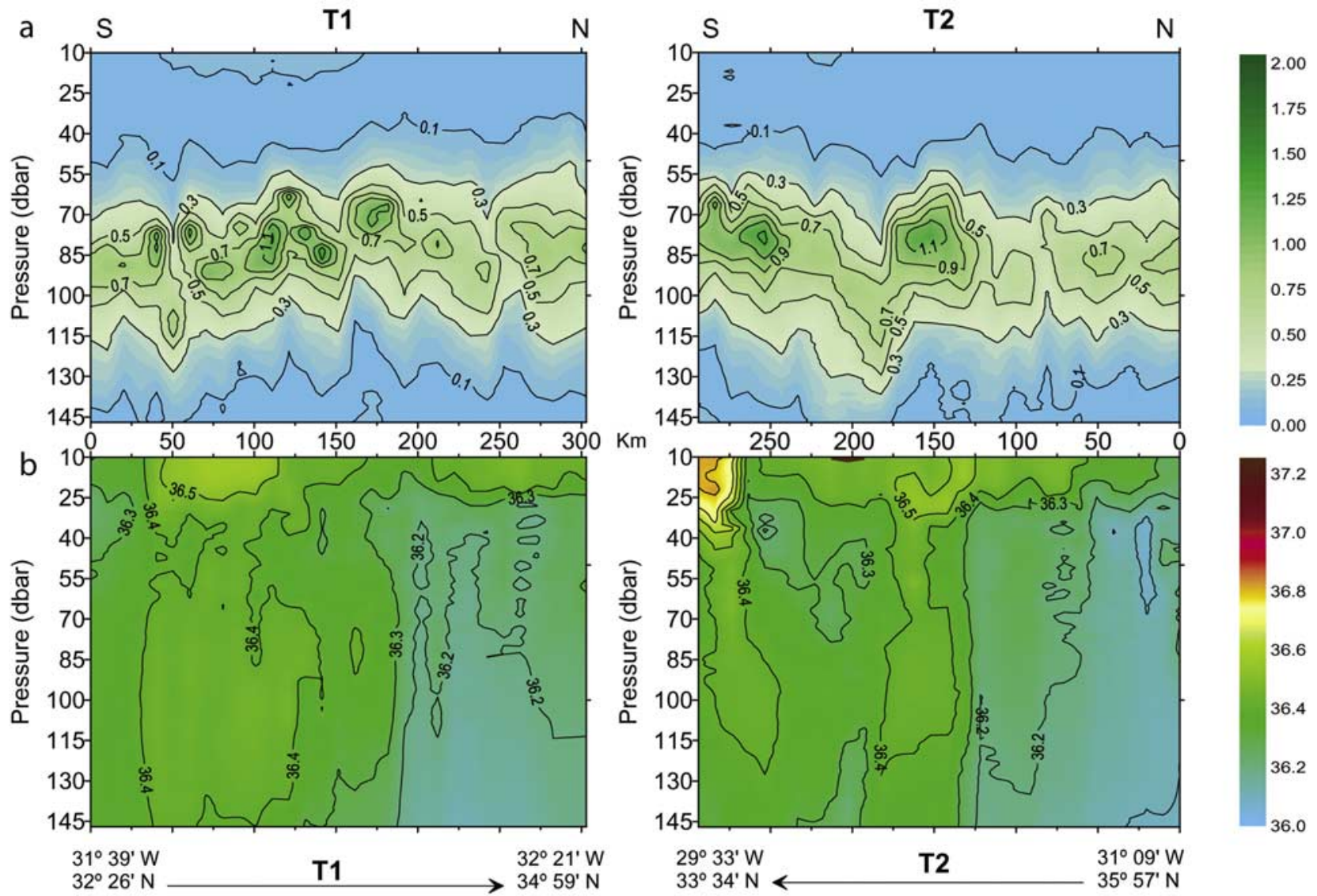

Figure 7. Vertical distributions of (a) chlorophyll $a\left(\mathrm{mg} \mathrm{Chl} \mathrm{m}^{-3}\right)$ and (b) salinity along the sections $\mathrm{T} 1$ and $\mathrm{T} 2$ of Figure 1a.

area around $33^{\circ} \mathrm{N}-34^{\circ} \mathrm{N}$. Even at $35^{\circ} \mathrm{N}$ and $25^{\circ} \mathrm{W}$, west of the anticyclonic eddy, strong northward currents substantiate the position of AF. Strong currents were also measured around the cyclonic eddy $\left(33.7^{\circ} \mathrm{N}, 22.7^{\circ} \mathrm{W}\right)$, mainly on the southern side. In the northeast corner a relatively weak current was probably related to the AzCC. In section A, the strong mesoscale structures seem to shift the AF to the north. However, the ADCP and geostrophic currents were mainly westward between the cyclonic eddy and $35^{\circ} \mathrm{N}$, and thus the true AF was located on the southern side of the cyclonic eddy. In addition, the SLA (Figure 1a) suggests that the water in the anticyclonic eddy had passed the northeastern side of the cyclonic eddy.

\subsection{Mesoscale and Submesoscale Coupling Between the AF and the Chlorophyll Field}

[32] The chlorophyll field showed short-scale coupling with the thermohaline field along several transects surveyed with the Undulator (Figures 7, 8, and 9). Over the whole area, the upper layer between the surface and 40-50 dbar was practically depleted in chlorophyll $\left(<0.1 \mathrm{mg} \mathrm{Chl} \mathrm{m}^{-3}\right)$. Along transect $\mathrm{T} 1$, which crosses the AF obliquely (Figure 1), the highest concentrations of the DCM over the whole area were located just to the south of the 36.3 isohaline that represents the AF at the DCM (Table 1). Immediately to the south of the AF $(190 \mathrm{~km})$ the shallowest DCM (68 dbar) was observed. The DCM tends to deepen toward $85 \mathrm{dbar}$ in the south, although reaching values of

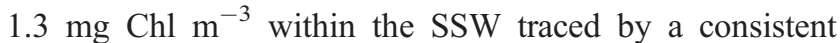
salinity of approximately 36.4 and temperature of $17.5^{\circ}-$ $18.5^{\circ} \mathrm{C}$ (not shown). The minimum concentrations of the

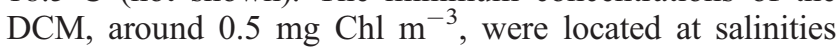
below 36.3 corresponding to the northern side of AF where the upwelling appears to be active. Transect T2 crosses the first anticyclonic meander of the AF between $36^{\circ} \mathrm{N}$ and $34^{\circ} \mathrm{N}$. The high values of the DCM on this cruise leg were situated south of the AF, identified by the 36.3 isohaline $(125 \mathrm{~km})$. Just south of the AF, a core with salinity 36.4 between 130 and $170 \mathrm{~km}$ along the transect contained a high and shallow DCM. Farther south, a clear decrease and deepening of the DCM occurred at salinities slightly below 36.3. Finally, at $250 \mathrm{~km}$ (close to $34^{\circ} \mathrm{N}$ ), the AC reappeared (to the right of the AF, Figure 1a) showing a clear saline front at the surface and high values of DCM (about $1.3 \mathrm{mg}$

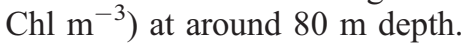

[33] The water mass dynamics in the east substantially modify the chlorophyll and thermohaline field coupling (Figure 8). The transect $\mathrm{T} 3$ from $30^{\circ} \mathrm{N}$ to $36^{\circ} \mathrm{N}$ crossed the $\mathrm{AF}$ at $32.5^{\circ} \mathrm{N}(300 \mathrm{~km})$ in a cyclonic meander (Figure 1a) and progressed along the cold and less saline intrusion (Figure 6). Within the first $325 \mathrm{~km}$ (south $32.5^{\circ} \mathrm{N}$ ) the presence of very saline and quasi-depleted chlorophyll waters at 60 dbar was evident. Below this depth was a thick water layer of salinity 36.6-36.85, typical of MMW, with a very deep $(>130 \mathrm{dbar})$ and low DCM $\left(<0.4 \mathrm{mg} \mathrm{Chl} \mathrm{m}^{-3}\right)$. These features constitute the main differences in the physical 


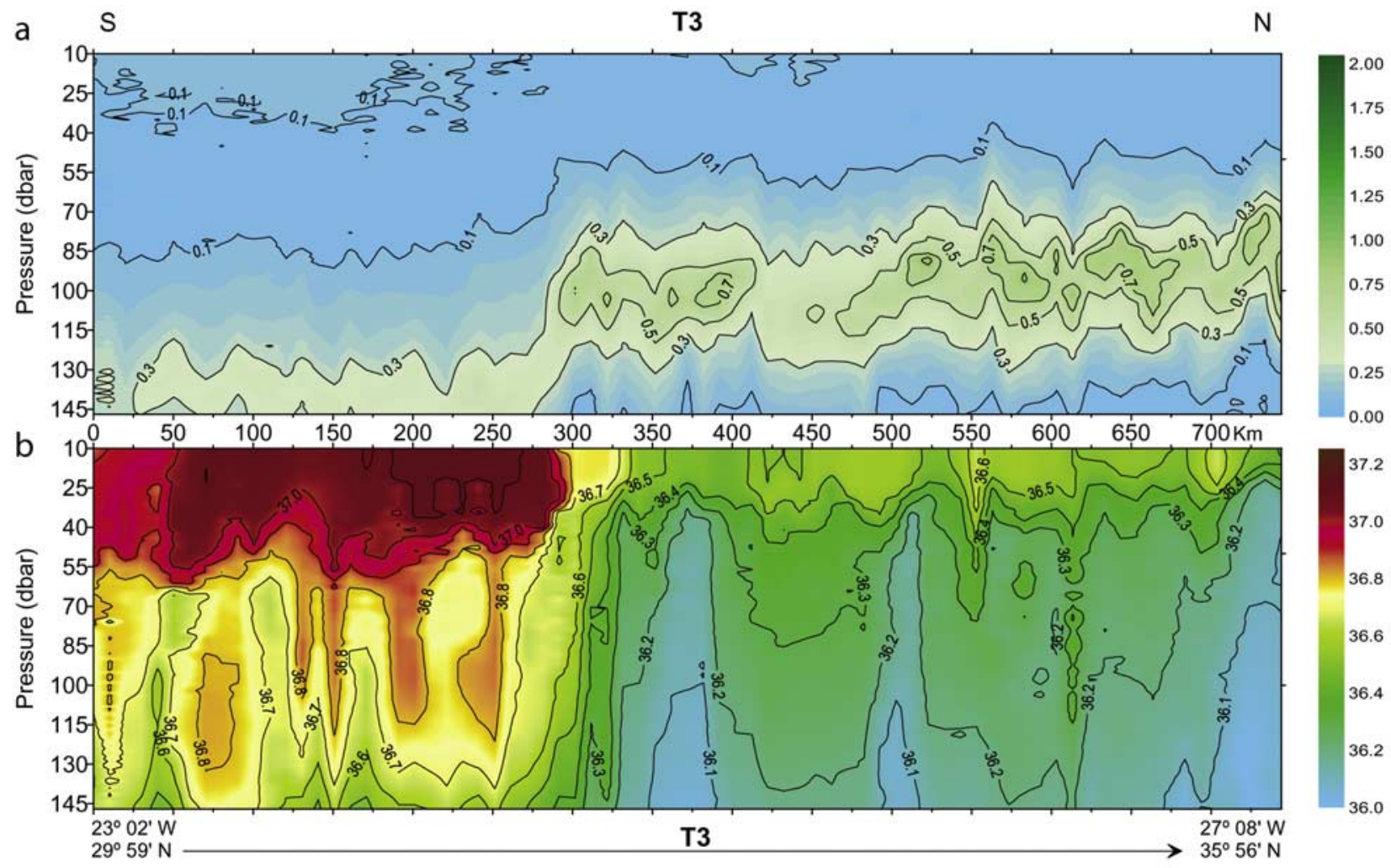

Figure 8. Vertical distributions of (a) chlorophyll $a\left(\mathrm{mg} \mathrm{Chl} \mathrm{m}^{-3}\right)$ and (b) salinity along the section T3 of Figure 1a.

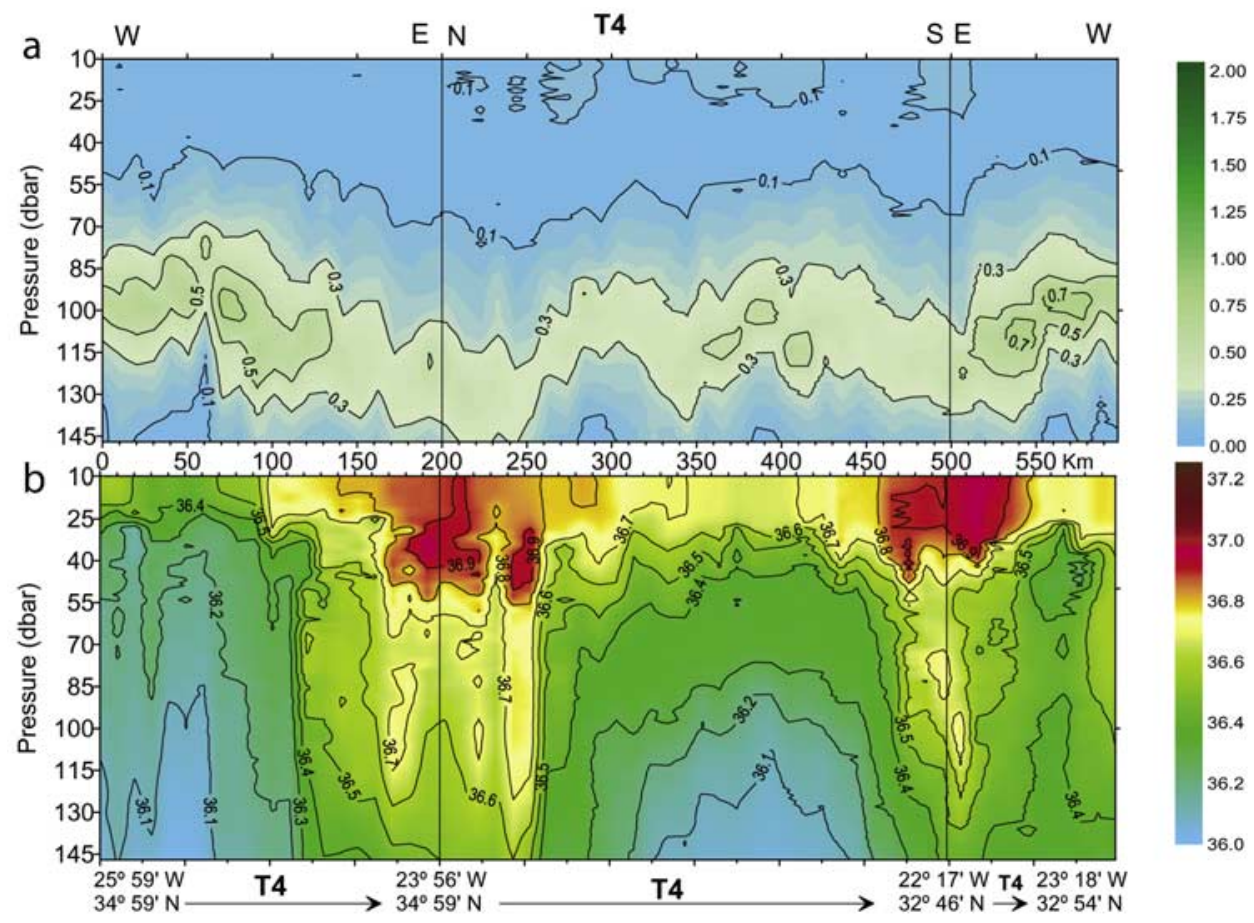

Figure 9. Vertical distributions of (a) chlorophyll $a\left(\mathrm{mg} \mathrm{Chl} \mathrm{m}^{-3}\right)$ and (b) salinity along the section T4 of Figure 1a. The continuous lines indicate changes of the section orientation. 
coupling of chlorophyll between the east and west of the study area. To the northwest, the maximum and shallowest DCM was found at the north side of the AF where salinity was low. Therefore, to the east of the seamount chain the southern side of the AF has a DCM with lower chlorophyll concentrations than to the west. A stable DCM at 100 dbar with values in the region of $0.7 \mathrm{mg} \mathrm{Chl} \mathrm{m}^{-3}$ characterized the northern side of the AF, and was associated with salinity minima at $380,520,570,625-675$, and $750 \mathrm{~km}$. North of $32.5^{\circ} \mathrm{N}$ the DCM tended toward shallower depths (100 to 80 dbar).

[34] The final transect (T4, Figures 1a and 9) comprises three tracks: (1) following $35^{\circ} \mathrm{N}$, T4 crossed the northern cold intrusion and the warm anticyclonic eddy; (2) thereafter, the section curved southward bisecting the cold cyclonic eddy, until (3) finally turning westward at the southern limb of the cold eddy upstream of the AC. The first $120 \mathrm{~km}$ of the section (Figure 9) was dominated by water with salinity below 36.3 and a DCM greater than $0.5 \mathrm{mg} \mathrm{Chl} \mathrm{m}^{-3}$ at 100 dbar. Two sharp fronts at 120 and $260 \mathrm{~km}$ enclosed a body of MMW traced by high salinity $(>36.6)$ with a deep DCM of very low chlorophyll content. This body of water originated from the southern side of the $\operatorname{AF}\left(32.5^{\circ} \mathrm{N}\right)$, signifying important water mass exchange across the AF. The cold seawater from the north appears to have evolved to form a cold eddy centered at $33.7^{\circ} \mathrm{N} 22.7^{\circ} \mathrm{W}$. From 270 to $470 \mathrm{~km}$ the section crossed the cold eddy toward the southeast. The DCM was almost $0.5 \mathrm{mg} \mathrm{Chl} \mathrm{m}^{-3}$ and deeper than $100 \mathrm{dbar}$. The eddy seems to be composed of water from the north intrusion with salinities lower than 36.3. Accordingly, it appears feasible that the chlorophyll could be advected from the north. Ahead of $510 \mathrm{~km}$ into the section, the southern limb of the eddy (along the AF) presented moderate salinities between 36.4 and 36.5, and associated with DCM concen-

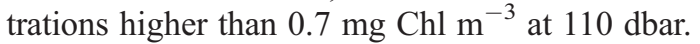

[35] The spatial variability of the DCM is shown in Figure 6b. From $31^{\circ} \mathrm{W}$ to $27^{\circ} \mathrm{W}$, the chlorophyll maximum $(>0.9 \mathrm{mg}$ $\left.\mathrm{Chl} \mathrm{m}{ }^{-3}\right)$ is located at the AC to the right of the AF. Where the AF exits the seamount chain and drifts to the south, the north-south gradients were opposite or practically negligible. With the exception of the area around the cyclonic eddy, generally on the southern side of the AF, moderate chlorophyll maxima were associated with the AC. The depth of the DCM (Figure 6b) partly resembles the SST (Figure 1b). There was a significant correlation between SST and the DCM depth $(\mathrm{r}=-0.75, \mathrm{n}=71)$, whereby the $25^{\circ} \mathrm{C}$ isotherm was parallel to the 100 -dbar DCM isoline. The DCM was shallower in the west than in the east and southeast. The sharpest gradient of DCM depth was found at $34^{\circ} \mathrm{N} 32^{\circ} \mathrm{W}$. Moreover, the DCM depth and concentration presented a significant correlation $(\mathrm{r}=-0.74, \mathrm{n}=71)$. The shallow DCM in the west contained a higher chlorophyll concentration than in the east on the deep DCM horizon. In addition, both salinity and temperature fields at the DCM horizon were well correlated $\left(r^{2}=0.93\right)$ and the $\theta / S$ line at the DCM (Figure 5b) is almost parallel to the $\theta / \mathrm{S}$ relationship at $150 \mathrm{dbar}$, thus suggesting a slight modification surface water by mixing.

\subsection{Biological and Physical Features of the Cyclonic Eddy}

[36] The $\theta / \mathrm{S}$ diagram in Figure $10 \mathrm{c}$ is constructed with data from nine CTD deep stations across a cold cyclonic eddy formed with water from the northern side of the AC and centered at $33.7^{\circ} \mathrm{N} 22.7^{\circ} \mathrm{W}$. Three clusters of $\theta / \mathrm{S}$ profiles can be discerned, and give sufficient information to characterize the eddy. The five stations closest to the center (Inner) show similar $\theta / \mathrm{S}$ profiles with small changes at 150 dbar a low salinity maximum $(<36.4)$. Comparisons may be drawn between these $\theta / \mathrm{S}$ profiles and those at section $\mathrm{A}$ at $33^{\circ} \mathrm{N}$ and $35^{\circ} \mathrm{N}$. The two most external stations presented two similar $\theta / \mathrm{S}$ profiles with a high salinity maximum similar to those on sections $\mathrm{A}$ and $\mathrm{B}$ at $31^{\circ} \mathrm{N}-$ $32^{\circ} \mathrm{N}$. Two intermediate stations had $\theta / \mathrm{S}$ profiles $\left(33.08^{\circ} \mathrm{N}\right.$ and $34.12^{\circ} \mathrm{N}$ ) characteristic of lateral mixing: The $\theta / \mathrm{S}$ properties of the upper layer were similar to those of the inner profiles, while the $\theta / \mathrm{S}$ properties below $150 \mathrm{dbar}$ presented attributes of the stations located in the outer part of the eddy. The same applies to the station at $34^{\circ} \mathrm{N}$ in section A (Figure 5a) and for the AF in section C. Therefore the water inside the eddy was trapped from the northern side of the AF, and hence the thermohaline and biological signals are similar to those described previously.

[37] During the Azores I cruise, a sampling exercise was planned to answer the following question: Do the cold water masses advected from the north side of the AC as cyclonic eddies represent an effective upwelling mechanism of water (and nutrients) as the doming of the isotherms in Figure 10 suggest? The thermohaline structure of the cold eddy shows typical doming of isotherms and isohalines. The $16^{\circ} \mathrm{C}$ isotherm and 36.2 isohaline experienced an elevation of $150 \mathrm{dbar}$ from the southern side of the eddy. However, the DCM was lacking a notable increase in the center since the DCM was higher in the southern limb of eddy. On the other hand, the depth $\left(Z_{\text {no3 }=1}\right)$ where nitrate concentration was 1 $\mu \mathrm{mol} \mathrm{kg} \mathrm{kg}^{-1}$ over the study area correlated well with the DCM depth, $Z_{\mathrm{DCM}}\left(\mathrm{Z}_{\mathrm{no3}=1}=1.02 \cdot \mathrm{Z}_{\mathrm{DCM}}, \mathrm{r}^{2}=0.76\right)$, but not with temperature. Therefore, at the DCM surface the cold water does not contain higher nutrients than the warm water. The seawater of approximately $16^{\circ} \mathrm{C}$ in the center of the eddy and on the northern side of the AF contained the same nitrate concentration $\left(1 \mu \mathrm{mol} \mathrm{kg}{ }^{-1}\right)$ as the $19^{\circ} \mathrm{C}$ seawater on the southern side.

[38] The vertical chlorophyll distribution in Figure 10 suggests that upwelling in the eddy occurs between the inner and outer water mass, and is less important in the eddy center. Accordingly, the upwelling of isotherms over the whole mesoscale structure does not imply true vertical advection of water enriched in nutrients. In fact, Lévy et al. [2001] have shown that the cyclonic eddies detached from the $\mathrm{AC}$ are mesoscale features subject to a general downwelling process, explained in terms of conservation of potential vorticity. Furthermore, the eddies are affected by submesoscale patterns of upwelling/downwelling dipoles and quadripoles that are the main reason for nutrient injection and phytoplankton subduction.

\section{Discussion}

[39] The Azores I cruise has enabled a better comprehension of several new features of the AF/AC system and their relationship with the biological field, especially in summer. In addition, field observations reported in this paper have shown for the first time that the salinity field in the upper $300 \mathrm{dbar}$ is the most adequate variable for detecting the AF, 

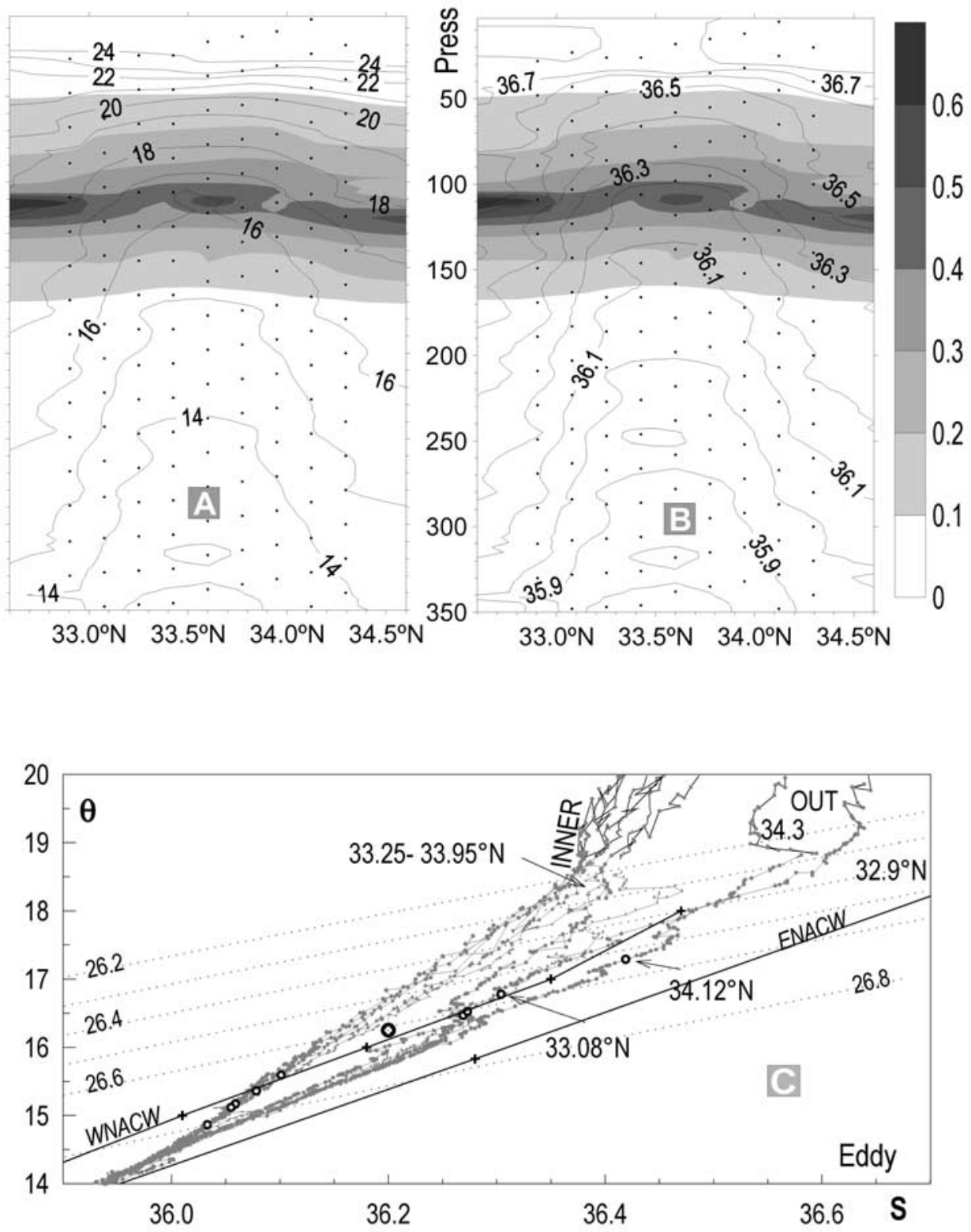

Figure 10. Vertical distribution of (a) temperature $\left({ }^{\circ} \mathrm{C}\right)$, and (b) salinity along the eddy centered at $33.7^{\circ} \mathrm{N}, 22.7^{\circ} \mathrm{W}$. Chlorophyll $a\left(\mathrm{mg} \mathrm{Chl} \mathrm{m}^{-3}\right)$ concentrations are given in gray scale. (c) $\theta-\mathrm{S}$ diagrams for stations sampled along the eddy. The density levels are indicated by doted lines. The 150-dbar surface at each station is marked by open points. The white cross represents $\theta-\mathrm{S}_{150}$ of the Azores Front (AF).

and also that the core of the AC is about $30 \mathrm{~nm}$ to the south (or on the right side) of the AF. Moreover, the water mass variability on the northern side of the AF is rather low, while to the south, two distinct water masses, SSW and MMW, were present to the west and east of $31^{\circ} \mathrm{W}$, respectively. As a consequence, there is an increase in the density field in the upper layers on the southern side of AF. A decrease of the transversal chlorophyll field showed similar characteristics to the physical field: The maximum and shallow (minimum and deep) DCM was observed on the southern side of the AF to the east (west) of $31^{\circ} \mathrm{W}$ whereas to the north side the concentration and depth of the DCM presented slight variability. No significant increase in DCM concentration was noted toward the center of the cyclonic eddy.
[40] Thermohaline analysis revealed that at approximately $10 \mathrm{~nm}$ the $\mathrm{AF}$ is rather narrow, in agreement with previous observations [Gould, 1985] and contrasting the relatively wide AC. A specific discrimination is not normally made between the AF and AC. Indeed, on the basis of early and large-scale observations, several criteria have been used to indiscriminately locate the AF and AC. The most established criterion was the use of temperature at the 200 dbar $\left(16^{\circ} \mathrm{C}\right)$ and $300 \mathrm{dbar}\left(15^{\circ} \mathrm{C}\right)$ horizons [Gould, 1985]. However, observations made in Azores I locate a thermohaline front at approximately $30 \mathrm{~nm}$ to the north of the AC core, and which forms the northern boundary of the AC with a strong horizontal shear. The criterion given by Gould [1985] is satisfactory for the AC, but for 200 dbar gives a temperature reference $0.63^{\circ} \mathrm{C}$ warmer than that our Azores I 
data established for the AF (Table 1). Dias et al. [1990] adopted the $16^{\circ} \mathrm{C}$ isotherm criterion in the temperature contour at 150 dbar to define the $\mathrm{AF}$, which is slightly cooler $\left(0.2^{\circ} \mathrm{C}\right)$ than that given here (Table 1$)$. Similarly, the AF was also well traced by the $16.2^{\circ} \mathrm{C}$ isotherm and 36.2 isohaline at 150 dbar [Tychensky et al., 1998] along the mesoscale structures found during the SEMAPHORE experiment carried out between $26^{\circ} \mathrm{W}$ to $21^{\circ} \mathrm{W}$ and $31^{\circ} \mathrm{N}$ to $36^{\circ} \mathrm{N}$ (from July to November 1993).

[41] The AC was frequently associated with a baroclinic front where no major changes in water masses occur [Müller and Siedler, 1992; Alves et al., 1999]. The classical water mass description related little difference between ENACW north of the AF and WNACW in the AC core [Gould, 1985; Ríos et al., 1992]. The water mass analysis above demonstrates that the AF can also be envisaged as a characteristic thermohaline tracer and, furthermore, that relevant changes in the water mass occur in the southern side of the AC. Pingree [1997] used the thermal gradient on the 26.5 isopycnal to locate the AF. However, the thermal and saline gradient is stronger at the 150-dbar horizon since this depth encompasses both the baroclinic gradient and the water mass variability on the surface of the salinity maximum of the central water. If not considered, this additional finding could lead to erroneous location of the AF, as was possibly the case reported by Pingree [1997] using data from the CD 66 cruise (March 1992). The $\theta / \mathrm{S}$ values of the winter mixed layer (thicker than $150 \mathrm{dbar}$ ) of the CD 66 cruise [Fernández and Pingree, 1996] recorded in a similar meridional section to Azores I section B are included in Figure $5 \mathrm{~b}$. Although there was a sharp change between $34^{\circ} \mathrm{N}$ and $35^{\circ} \mathrm{N}$, the $\theta / \mathrm{S}$ properties at $35^{\circ} \mathrm{N}$ suggest that the AF was further north than $35^{\circ} \mathrm{N}$, in agreement with the northward shift of the AF in winter. South of $34^{\circ} \mathrm{N}$, a very saline mode of ENACW was found in winter in comparison to observations in August 1998, probably due to the location of the westward limb of the anticyclonic recirculation when the AF shifts to the north [Pingree, 1997]. This implies that the high transport given by Pingree [1997], approximately $26 \mathrm{~Sv}$, probably represents the transport inside a cyclonic eddy or storm on the warm side of the $\mathrm{AC}$ system and, in addition, that the AC circulated slightly to the north of the CD 66 cruise area.

[42] Interesting features of the data are the high correlations between potential temperature and salinity at different depths (surface, DCM, 150 dbar, $200 \mathrm{dbar}$, and $300 \mathrm{dbar}$ ). This, however, is not the case for SST (Table 1), thus precluding the use of the satellite infrared data in AF detection. From the thermocline down to $300 \mathrm{dbar}$, the AF separates colder and less saline waters in the north from warmer and saltier waters in the south. The SSS is more variable than the salinity at $150 \mathrm{dbar}$, and forces the slope between SSS and salinity at 150 dbar to be greater than unity (Table 1). The saline front at the surface is stronger than the AF below the thermocline and presents a shift to the south. These observations agree with the southward shift of the AF at the surface in summer [Stramma and Siedler, 1988; Stramma and Müller, 1989], although in winter the opposite trend has been noted [Stramma and Müller, 1989; Pingree et al., 1999].

[43] The anomalous large-scale SST distribution suggests a northeastward surface advection of warm waters, whereas cold water was driven by the trade winds along the southern side of the AF. The most notable influence was over the north-south asymmetric buoyancy flux to the east of the study area. The presence of the relatively cold and saline water in the upper layer in the southeast is related with heat and water loss in the area around Madeira, which favors the water mass formation of MMW. The area between $15^{\circ} \mathrm{W}-$ $30^{\circ} \mathrm{W}$ and $28^{\circ} \mathrm{N}-40^{\circ} \mathrm{N}$ has an annual average deficit of water (E-P > 0) and lost of heat [Schmitt et al., 1989; Marshall et al., 1993], and these factors determine the salinization SSW to made MMW. New et al. [1995], using the Miami isopycnic coordinated ocean model (MICOM) for the North Atlantic, also obtained a progressive increase of salinity and temperature on the 26.7 isopycnic surface along the south side of the $\operatorname{AF}\left(32^{\circ} \mathrm{W}\right)$ from $28^{\circ} \mathrm{W}$ to $15^{\circ} \mathrm{W}$. The model was forced by surface flux of heat, water, and momentum. However, despite the fact that the main features of the AC and adjacent countercurrents are well modeled, the resolution $\left(1 / 3^{\circ}\right)$ does not allow the mesoscale structures to be resolved. On the southern side, the AC flows in a field of progressively increasing density to the east on the south side as the water mass evolves from SSW to MMW, the latter generally situated eastward of $31^{\circ} \mathrm{W}$. Thus the observed large-scale meridional gradient in the density field induced a decrease of baroclinic forcing and eastward water transport. In summary, the weakening, meandering, and instability of the AC may also be due, in part, to anomalous water and heat fluxes in the outcrop area of MMW.

[44] The magnitudes of large-scale water transport are similar to those previously recorded in the area. To the west of $26^{\circ} \mathrm{W}$ water flux was $15-16 \mathrm{~Sv}$, whereas along $21^{\circ} \mathrm{W}$ the corresponding value was $6 \mathrm{~Sv}$. Moreover, $75 \%$ of the total water transport by the AC was confined to the upper $800 \mathrm{~m}$ of the water column. An eastward weakening of the AC and strengthening of countercurrents was also observed. Paillet and Mercier [1997] have described a similar sequence of events with the aid of inverse methods. In addition, the front observed between $35^{\circ} \mathrm{N}$ and $36^{\circ} \mathrm{N}$ in section $\mathrm{A}$ and the corresponding eastward current seems to be associated with a southern branch of NAC circulating northeast of the Azores Islands toward the Madeira Islands. These findings have been described previously by Klein and Siedler [1989] and Pollard et al. [1996], and modeled by Paillet and Mercier [1997]. The weakening of the AC in the east does not affect the cross thermohaline gradient in the AF because the presence of MMW. At the isopycnal 26.5 the thermal gradients were $0.6^{\circ} \mathrm{C}, 1.3^{\circ} \mathrm{C}$ and $1.2^{\circ} \mathrm{C}$ along sections $\mathrm{C}, \mathrm{B}$, and A, respectively. Pingree and Sinha [1998] observed a similar gradient along $26.5^{\circ} \mathrm{W}$.

[45] High spatial resolution of CTD stations and the Undulator system were able to describe the mesoscale structure in detail (Figure 6). The ADCP measurements agreed with the large-scale geostrophic field and the salinity field at $150 \mathrm{~m}$. A good correspondence between geostrophic and ADCP measurements was also observed in the cold eddy $\left(33.7^{\circ} \mathrm{N}, 22.7^{\circ} \mathrm{W}\right)$. These observed features and salinity traced AF (Figure 6) agree with earlier descriptions. The $\mathrm{AC}$ behaves like a narrow jet between MAR and $31^{\circ} \mathrm{W}$, thereafter becoming a meandering current upon reaching the seamount chain between $31^{\circ} \mathrm{W}$ and $29^{\circ} \mathrm{W}$. The earlier detailed descriptions of the $\mathrm{AC}$ west of $28^{\circ} \mathrm{W}$ corresponded to winter, depicting the $\mathrm{AC}$ as a current moving southeast of 
Plato seamount until entering a meander before crossing $31^{\circ} \mathrm{W}$ [Gould, 1985 ] or forming a big cyclonic eddy around $32.5^{\circ} \mathrm{N}$ and $32.5^{\circ} \mathrm{W}$ [Pingree, 1997]. Alves et al. [1999], using a primitive numerical equation model, showed that the mesoscale patterns in the Azores region are largely determined by baroclinic instability. In general, Alves et al. [1999] assumed only thermohaline meridional variations, invariant vertical density, and north-south gradients. Anticyclonic (northward) eddies shedding from the meandering AC were modeled with short lifetimes ( $\sim 15$ days), although both are clearly observed in Figure 6. Further, small-scale observations of the AC signal in section $C$ (Figure 4c) showed upwelling on the northern edge of the $\mathrm{AF}$ and downwelling on the southern side of $\mathrm{AC}$, describing a righthanded screw pattern along the AC. However, this is not the general trend of southward/northward upwelling/downwelling of the AC, stated theoretically by Strass [1992] and observed by Rudnick [1996]. Indeed, the vertical velocities obtained from an average meridional section with the model results of Alves et al. [1999] show a more intricate vertical structure, upwelling in the core of the AC and downwelling on both sides.

[46] To the east, in an earlier SEMAPHORE experiment $\left(18^{\circ} \mathrm{W}-28^{\circ} \mathrm{W}, 31^{\circ} \mathrm{N}-36^{\circ} \mathrm{N}\right.$, July-November 1993$)$ the surface circulation and the subsuperficial thermohaline and geostrophic fields were described [Tychensky et al., 1998; Reverdin and Hernandez, 2000]. A similar mesoscale structure with eddies and meanders was found during the SEMAPHORE experiment where the main current and several mesoscale structures seem to have been relatively persistent (months) while others were short-lived (less a month). The lengths of the mesoscale structures observed here and in SEMAPHORE were of the order of the AC width $(140 \mathrm{~km})$. Previously, between $24^{\circ} \mathrm{W}-18^{\circ} \mathrm{W}$ and $31.5^{\circ} \mathrm{N}-36^{\circ} \mathrm{N}$, Käse and Siedler [1982] and Käse et al. [1985] also described similar mesoscale features to those of the SEMAPHORE experiment. From the GEOSAT altimeter, maximum variability of sea level anomaly occurs along $34^{\circ} \mathrm{N}$ [Le Traon and De Mey, 1994] with a maximum 17day isocorrelation near to the warm eddy at $24^{\circ} \mathrm{W}$ and $35^{\circ} \mathrm{N}$ reported here. Using data from drogued buoys spanning 9 years, Pingree [1997] also found a zone with high eddy kinetics $\left(>100 \mathrm{~m}^{2} \mathrm{~s}^{-2}\right)$ along the $\mathrm{AF}$ near $34^{\circ} \mathrm{N}$ latitude, reaching a maximum $\left(>200 \mathrm{~m}^{2} \mathrm{~s}^{-2}\right)$ at $22.5^{\circ} \mathrm{W}$ and $34^{\circ} \mathrm{N}$, very close to the cold eddy. The area between $20^{\circ} \mathrm{W}$ and $26^{\circ} \mathrm{W}$ around $34^{\circ} \mathrm{N}$ shows persistent cyclonic eddy circulation, probably related to $\mathrm{AC}$ weakening as the north-south baroclinic gradient decreases due to eastward transition from SSW to MMW. On the other hand, both early numerical [Kielmann and Käse, 1985] and recent models [Alves et al., 1999] fail to reproduce the coherent cyclonic eddies shed from the AC, and are only capable of modeling coherent anticyclonic eddies and weaker cyclonic filaments. However, Lévy et al. [2001] did manage to model cyclonic eddies, although only when the horizontal resolution of the numerical model was raised to $2 \mathrm{~km}(\sim 20$ times the internal Rossby radius of deformation). Therefore submesoscale physics also seems to play an important role in the stability of coherent cyclonic eddies.

[47] The mean position and zonal extent of the AC is not readily derived from altimeter data [Le Traon et al., 1998; Pingree et al., 1999] since the reference state is removed to determine the SLA. The mesoscale structures observed in the salinity distribution at $150 \mathrm{dbar}$ showed good agreement with the SLA map (Figure 1a). However, when SLA minima are engendered by an increase in $\mathrm{AC}$ speed, isolated SLA minima such as at $32^{\circ} \mathrm{W}$ and $34^{\circ} \mathrm{N}$ may be indicative of eddies. The mesoscale structures were associated by dipole or tripole structures in the SLA maps.

[48] Fronts are generally related to sharp changes in chlorophyll distribution and biomass enhancement [ $L e$ Fevre, 1986]. Several works on the coupling between physics and biology in oceanic fronts relate to the Gulf Stream [Hitchcock et al., 1993; Lohrenz et al., 1993] and Azores current [Fasham et al., 1985; Fernández and Pingree, 1996]. The description of the large-scale chlorophyll field is similar to some previous findings in the Azores area, mainly in late winter and spring. The DCM concentrations in the west were unexpected since the DCM tends to decrease in concentration and deepen after the spring bloom. South of the Azores Islands, Fasham et al. [1985] exhaustively studied the DCM along a cyclonic AF meander between $35^{\circ} \mathrm{W}$ and $28^{\circ} \mathrm{W}$. Fasham et al. [1985] made a unique small-scale study of the coupling between the physical and chlorophyll fields, and discovered that the AF did not enhance chlorophyll concentrations, and a smaller and deeper DCM on the southern side of the AF than the north. These workers also recorded persistently low values of $0.1-0.2 \mathrm{mg} \mathrm{Chl} \mathrm{m}^{-3}$ between 80 and $100 \mathrm{dbar}$ on the southern side of the AF, and moderate concentrations of $0.4-0.8 \mathrm{mg} \mathrm{Chl} \mathrm{m}{ }^{-3}$ between 50 and 70 dbar in the north. Moreover, they described a slight increase and an average deepening of the DCM by 8 dbar from April to May. Fasham et al. [1985] located the DCM at 30-40 dbar below the pycnocline. Other kinds of studies carried out at $33^{\circ} \mathrm{N} 20^{\circ} \mathrm{W}$ in spring also reported high DCM concentrations $\left(0.8 \mathrm{mg} \mathrm{Chl} \mathrm{m}^{-3}\right)$ at $70 \mathrm{dbar}$ [Jochem and Zeitschel, 1993]. During August 1998, the pycnocline was situated between 40 and $60 \mathrm{dbar}$, about half the depth of the DCM. Thus the separation between the pycnocline and DCM increases during the summer at a similar rate as Fasham et al. [1985] found between April and May. However, chlorophyll concentration presented a significant increase between spring and summer, probably due to increased light penetration. The average light in the surface water during spring was $44 \mathrm{~mol} \mathrm{~m}^{-2}$ day $^{-1}$ [Fasham et al., 1985], amounting to approximately $80 \%$ of the average light recorded in August $\left(55 \mathrm{~mol} \mathrm{~m}^{-2}\right.$ day $\left.^{-1}\right)$. The $1 \%$ light level was $90 \pm 10 \mathrm{dbar}(\mathrm{n}=18)$ in summer, thus enabling the plankton to live in a thick water layer between 60 and 140 dbar. Fasham et al. [1985] further showed that $Z_{\text {no } 3=1}$ is deeper on the southern side of the AF, while in Azores I the $Z_{\text {no3=1 }}$ was shallower on the southern side of the AF to the west of $29^{\circ} \mathrm{W}$. The variability of the integrated chlorophyll down to 200 dbar obtained from CTD profiles was approximately $50 \%$ lower than the variability of the DCM. Fasham et al. [1985] found a similar pattern in spring. The low values of DCM were partially compensated by a moderate level of chlorophyll in deep waters. The 200-dbar integrated chlorophyll ranged from $50 \mathrm{mg} \mathrm{Chl} \mathrm{m}{ }^{-2}$ in the west to $26 \mathrm{mg} \mathrm{Chl} \mathrm{m}{ }^{-2}$ in the southeast, with a positive and significant correlation $\left(\mathrm{r}^{2}=0.54\right)$ with SST.

[49] We could find only one literature reference to the increase in chlorophyll along the AF [Fernández and 
Pingree, 1996]. These authors reported a chlorophyll maximum in late winter 1992 with values below $0.3 \mathrm{mg} \mathrm{Chl}$ $\mathrm{m}^{-3}$ in the upper mixed layer close to the AF. However, observing their Figure 8 in detail, two maxima of fluorescence can be discerned on either side of the AC. These maxima were associated with two pycnostads of two different modes of ENACW, and therefore the chlorophyll maximum was on both sides of the AF. In the large-scale description shown here, the southern side of the AC presented the highest chlorophyll levels, mainly where the $\mathrm{AC}$ is strong. However, this pattern is superimposed by a smooth north-south decreasing DCM gradient mainly to the east. Fasham et al. [1985] also showed a significant correlation between the magnitude and depth of the DCM in a region substantially smaller than the one studied here.

[50] The most striking feature of the chlorophyll field was the presence of a deep and rich DCM compared with previous observations made in spring. In summer, the DCM was about $30 \mathrm{~m}$ deeper than spring, with higher chlorophyll values, presumably due to deep light penetration over the summer solstice. Maximum summer chlorophyll values were observed on the southern side of the AC, whereas the opposite occurred in spring west of $26^{\circ} \mathrm{W}$. In addition, high chlorophyll concentrations were recorded west of $30^{\circ} \mathrm{W}$, mainly on the southern side of the AF, and a deep DCM of low concentration was observed where MMW is dominant. The AC seems to transport water with high chlorophyll content into a chlorophyll-poor region. Chlorophyll concentrations also decreased where the AC became weaker, saltier, and exhausted in nutrients. The vertical cyclonic circulation in the $\mathrm{AC}$ may to some extent explain the higher chlorophyll values on the southern side of the AC where downwelling can accumulate planktonic species.

[51] The Azores I observations have enabled the AC and $\mathrm{AF}$ to be differentiated and the water mass variability in the upper North Atlantic Central Water to be clarified. The eastward variability in water masses could be a source of baroclinic instability, largely ignored in mesoscale models. However, the large-scale models analyzed and compared by New et al. [2001] could reproduce the water mass modification in the upper layer because they incorporated Levitus' climatology as external forcing. The cyclonic eddies shed from the meandering $\mathrm{AC}$ enclosed cold and fresh water from the northern side of the front, although the vertical temperature signal in the center of cyclonic eddies does not signify a net upwelling of the nutrient-rich water. Moreover, the chlorophyll field did not present an enhancement of primary production. However, on the border of the cyclonic eddy described previously, where the chlorophyll level is enhanced, a submesoscale upwelling-downwelling seems to have occurred. Coupled with the chlorophyll patchiness observed with the Undulator transects and the submesoscale features found in the AC/AF (Section C), these findings are clear signals of the importance of submesoscale physics and biological processes in the Azores region.

[52] Acknowledgments. We would like to thank the master, officers and crew of BIO Hesperides and all participants of the AZORES I cruise. We are grateful to the technicians and staff of the UGBO for their assistance with the CTD, Nv-Suttle, and ADCP measurements. Also, we are very grateful to G. Siedler for his careful revision. The EU project MAS3-CT960060 and CICYT project MAR1997-1729-CE supported this work. The altimeter maps were produced by the CLS Space Oceanography Division as part of the European Union's Environment and Climate project. We thank Andrew Dale for English revision.

\section{References}

Alves, M. L. G. R., and A. Colin de Verdière, Instability dynamics of a subtropical jet and applications to Azores Fronts Current System: EddyDriven mean flow, J. Phys. Oceanogr., 29, 837-864, 1999.

Cromwell, D., P. G. Challenor, A. L. New, and R. D. Pingree, Persistent westward flow in the Azores Current as seen from altimetry and hydrography, J. Geophys. Res., 101, 11,923-11,933, 1996.

Dias, C. M. A., M. H. Cavaco, and J. L. Pissarra, Observation of the Azores front in July 1987 and June 1989, ICES J. Mar. Sci., C34, 1990.

Dietrich, G., K. Kalle, W. Krauss, and G. Siedler, General Oceanography, 626 pp., John Wiley, New York, 1975.

Dixon, T. H., An introduction to the global positioning system and some geological applications, Rev. Geophys., 29(2), 249-276, 1991.

Emery, W. J., and J. Meincke, Global water masses: Summary and review, Oceanol. Acta, 9, 383-391, 1986.

Fasham, M. J. R., T. Platt, B. Irwin, and K. Jones, Factors affecting the spatial pattern of the deep chlorophyll maximum in the region of the Azores front, Prog. Oceanogr., 14, 129-165, 1985.

Fernández, E., and R. D. Pingree, Coupling between physical and biological fields in the North Atlantic subtropical front southeast of the Azores, Deep Sea Res., Part I, 43, 1369-1393, 1996.

Fiúza, A. F. G., Hidrologia e dinamica das augas costeiras de Portugal, Ph.D. thesis, Lisbon Univ., Lisbon, 1984.

Fiúza, A. F. G., and D. Halpern, Hydrographic observations of the Canary current between $21 \mathrm{~N}$ and $25.5 \mathrm{~N}$ in March/April 1974, Rapp. P. V. Reun. Cons. Int. Explor. Mer, 180, 58-64, 1982.

Gould, W. J., Physical oceanography of the Azores front, Prog. Oceanogr, 14, $167-190,1985$.

Griffiths, G., Using 3DF heading for improving underway ADCP data, J. Atmos. Oceanic Technol., 11(4), 1135-1143, 1994.

Hitchcock, G. L., A. J. Mariano, and T. Rossby, Mesoscale pigment fields in the Gulf Stream: Observations in a meander crest and trough, J. Geophys. Res., 98, 8425-8445, 1993.

Iselin, C. O., A study of the circulation of the western north Atlantic, Phys. Oceanogr. Meteorol., 4, 1-101, 1936.

Jochem, F. J., and B. Zeitzschel, Productivity regime and phytoplankton size structure in the tropical North Atlantic in spring 1989, Deep Sea Res., Part II, 40, 495-519, 1993.

Käse, R. H., and G. Siedler, Meandering of the subtropical front, south-east of Azores, Nature, 300, 245-246, 1982.

Käse, R. H., W. Zenk, T. B. Sanford, and W. Hiller, Currents, fronts and eddy fluxes in the Canary basin, Prog. Oceanogr., 14, 231-257, 1985.

Kielmann, J., and R. H. Käse, Numerical modeling of meander and eddy formation in the Azores Current Frontal Zone, J. Phys. Oceanogr., 17, $529-541,1987$.

King, B. A., and E. B. Cooper, Comparison of ship's heading determined from an array of GPS antennas with heading from conventional gyrocompass measurements, Deep Sea Res., Part I, 40, 2207-2216, 1993.

Klein, B., and G. Siedler, On the origin of the Azores current, J. Geophys. Res., 94, 6159-6168, 1989.

Krauss, W., and J. Meincke, Drifting buoy trajectories in the North Atlantic Current, Nature, 296, 737-740, 1982.

Le Fevre, J., Aspects of the biology of frontal systems, Adv. Mar. Biol., 23, $163-299,1986$.

Le Traon, P. Y., and P. De Mey, The eddy field associated with the Azores Front east of the Mid-Atlantic Ridge as observed by Geosat altimeter, J. Geophys. Res., 99, 9907-9923, 1994.

Le Traon, P. Y., F. Nadal, and N. Ducet, An improved mapping method of multi-satellite altimeter data, J. Atmos. Oceanic Technol., 15, 522-534, 1998.

Lévy, M., P. Klein, and A. M. Treguier, Impacts of sub-mesoscale physics on production and subduction of phytoplankton in an oligotrophic regime, J. Mar. Res., 59, 535-565, 2001

Lohrenz, S. E., J. J. Cullen, D. A. Phinney, D. B. Olson, and C. S. Yentsch, Distribution of pigments and primary production in a Gulf Stream Meander, J. Geophys. Res., 98, 14,545-14,560, 1993.

Marshall, J. C., A. J. G. Nurser, and R. G. Williams, Inferring the subduction rate and period over North Atlantic, J. Phys. Oceanogr., 23, 13151329, 1993.

Müller, T. J., and G. Siedler, Multi-year current time series in the eastern North Atlantic Ocean, J. Mar. Res., 50, 63-98, 1992.

New, A. L., R. Bleck, Y. Jia, R. Marsh, M. Huddleston, and S. Barnard, An isopycnic model study of the north Atlantic: I. Model experiment, J. Phys. Oceanogr., 25, 2667-2699, 1995.

New, A. L., Y. Jia, M. Coulibaly, and J. Dengg, On the role of the Azores Current in the ventilation of the North Atlantic Ocean, Prog. Oceanogr., 48, 163-194, 2001. 
Onken, R., The Azores countercurrent, J. Phys. Oceanogr., 23, 1638-1646, 1993.

Paillet, J., and H. Mercier, An inverse model of the eastern North Atlantic general circulation and thermocline ventilation, Deep Sea Res., Part I, 44, $1293-1328,1997$.

Pingree, R. D., The eastern subtropical gyre (North Atlantic): Flow rings recirculations structure and subduction, J. Mar. Biol. Assoc. U. K., 77, 573-624, 1997.

Pingree, R. D., and B. Sinha, Dynamic topography (ERS-1/2 and Seatruth) of subtropical ring (STORM 0) in the storm corridor $\left(32-34^{\circ} \mathrm{N}\right.$, eastern basin, North Atlantic Ocean), J. Mar. Biol. Assoc. U. K., 78, 351-376, 1998.

Pingree, R. D., C. García-Soto, and B. Sinha, Position and structure of the Subtropical/Azores Front region from combined Lagrangian and remote sensing (IR/altimeter/SeaWifs) measurements, J. Mar. Biol. Assoc. U. K., 79, 769-792, 1999.

Pollard, R. T., and S. Pu, Structure and circulation of the upper Atlantic Ocean northeast of the Azores, Prog. Oceanogr., 14, 443-462, 1985.

Pollard, R. T., M. J. Griffiths, S. A. Cunningham, J. F. Read, F. F. Perez, and A. F. Ríos, Vivaldi 1991-A study of the formation, circulation and ventilation of Eastern North Atlantic Central Water, Prog. Oceanogr., 37, $167-192,1996$.

Reverdin, G. F., and F. Hernandez, Variability of the Azores Current during October-December 1993, J. Mar. Syst., 29, 101-123, 2000.

Ríos, A., F. F. Perez, and F. Fraga, Water masses in the upper and middle North Atlantic Ocean east of the Azores, Deep Sea Res., Part I, 39, $645-$ 658, 1992.

Rudnick, D. L., Intensive surveys of the Azores Front: 2. Inferring the geostrophic and vertical velocity fields, J. Geophys. Res., 101, 16,291-16,303, 1996.

Saunders, P. M., Circulation in the eastern North Atlantic, J. Mar. Res., 40, $641-657,1982$.

Schmitt, R. W., Form of the temperature-salinity relationship in the central water: Evidence for double-diffusive mixing, J. Phys. Oceanogr., 11, 1015-1026, 1981.
Schmitt, R. W., P. S. Bogden, and C. L. Dorman, Evaporation minus precipitation and density fluxes for the North Atlantic, J. Phys. Oceanogr., 19, 1208-1221, 1989.

Siedler, G., W. Zenk, and W. J. Emery, Strong current events related to a subtropical front in the Northeast Atlantic, J. Phys. Oceanogr., 15, 885897, 1985.

Siedler, G., A. Kuhl, and W. Zenk, The Madeira mode water, J. Phys. Oceanogr., 17, 1561-1970, 1987.

Stramma, L., Geostrophic transport in the Warm Water Sphere of eastern subtropical North Atlantic, J. Mar. Res., 42, 537-558, 1984.

Stramma, L., and H. J. Isemer, Seasonal variability of meridional temperature fluxes in the eastern North Atlantic Ocean, J. Mar. Res., 46, $281-$ 299, 1988.

Stramma, L., and T. J. Müller, Some observations of the Azores Current and the North Equatorial Current, J. Geophys. Res., 94, 3181-3186, 1989.

Stramma, L., and G. Siedler, Seasonal changes in the North Atlantic subtropical gyre, J. Geophys. Res., 93, 8111-8118, 1988.

Strass, V. J., Chlorophyll patchiness caused by mesoscale upwelling at fronts, Deep Sea Res., 39, 75-96, 1992.

Sy, A., Investigation of large-scale circulation patterns in the central North Atlantic: The North Atlantic Current, the Azores Current, and the Mediterranean water plume in the area of the Mid-Atlantic Ridge, Deep Sea Res., Part I, 35, 383-413, 1988.

Talley, L. D., and M. E. Raymer, Eighteen degree water variability, J. Mar. Res., 40, 757-775, 1982.

Tychensky, A., P. Y. Le Traon, F. Hernandez, and D. Jourdan, Large structures and temporal change in the Azores Front during the Semaphore experiment, J. Geophys. Res., 103, 25,009-25,027, 1998.

Yentsch, C. S., and D. W. Menzel, A method for the determination of phytoplankton chlorophyll and phaeophytin by fluorescence, Deep Sea Res., 10, 221-231, 1963.

M. Gilcoto, F. F. Pérez, and A. F. Ríos, Departamento de Oceanografía, Instituto de Investigacións Mariñas (CSIC), Eduardo Cabello 6, 36208, Vigo, Spain. (migil@iim.csic.es; fiz@iim.csic.es; aida@iim.csic.es) 